\title{
Correlation Between Structure, Chromaticity, and Dielectric Properties of Calcium Copper Pyrophosphates, $\mathrm{Ca}_{2-x} \mathrm{Cu}_{x} \mathrm{P}_{2} \mathrm{O}_{7}$
}

\section{Rattanai Baitahe}

King Mongkut's Institute of Technology Ladkrabang

Chuchai Sronsri

King Mongkut's Institute of Technology Ladkrabang

\section{Somphob Thompho}

Chulalongkorn University

\section{Kittichai Chaiseedad}

King Mongkut's University of Technology Thonburi

\section{Banjong Boonchom ( $\nabla$ kbbanjon@gmail.com )}

King Mongkut's Institute of Technology Ladkrabang

\section{Research Article}

Keywords: Binary metal pyrophosphate, Dielectric and optical properties, Vibrational characteristic, Rietveld refinement analysis, X-ray absorption

Posted Date: February 3rd, 2022

DOI: https://doi.org/10.21203/rs.3.rs-1304765/v1

License: (c) (i) This work is licensed under a Creative Commons Attribution 4.0 International License. Read Full License 


\section{Abstract}

Discoveries of the correlation between the physical properties and structure of the materials are interesting in the field of the material science and chemical engineering. This work investigated the correlation between the structure, chromaticity, and dielectric properties of calcium copper pyrophosphates, $\mathrm{Ca}_{2-x} \mathrm{Cu}_{x} \mathrm{P}_{2} \mathrm{O}_{7}$. The solid state thermal decomposition reaction was employed to synthesize the $\mathrm{Ca}_{2-x} \mathrm{Cu}_{x} \mathrm{P}_{2} \mathrm{O}_{7}$ by varying the mole ratio between $\mathrm{Ca}$ and $\mathrm{Cu}$. The structure and crystallography of the pyrophosphate compounds were identified and confirmed by using an X-ray diffraction (XRD) technique. The Rietveld refinement method and the extended X-ray absorption fine structure (EXAFS) least-squares fitting technique were also applied to refine the sample crystal structure. The bond angle and bond length of samples were also obtained from the refinement method. The X-ray absorption edge energies $\left(E_{0}\right)$ of the synthesized compounds were investigated and the obtained results confirmed the formation of the binary metal pyrophosphates $\left(\mathrm{Ca}_{2-x} \mathrm{Cu}_{x} \mathrm{P}_{2} \mathrm{O}_{7}\right)$. The image sensor result of the $\mathrm{Cu}_{2} \mathrm{P}_{2} \mathrm{O}_{7}$ sample $(x=2.00)$ illustrated a yellowish-green color, while other compounds $(x=0.50-1.50)$ presented color tones that changed from blue-green to bluish-green. The dielectric constant $\left(\varepsilon_{\mathrm{r}}\right)$ of the synthesized $\mathrm{Ca}_{2-x} \mathrm{Cu}_{x} \mathrm{P}_{2} \mathrm{O}_{7}$ were calculated by using the Clausius-Mossotti relation, and the highest $\varepsilon_{\mathrm{r}}$ was observed for $\mathrm{Ca}_{2} \mathrm{P}_{2} \mathrm{O}_{7}$. The Raman and Fourier transform infrared (FTIR) spectrophotometers were employed to characterize and confirm the vibrational characteristics of the $\mathrm{P}_{2} \mathrm{O}_{7}{ }^{4-}$ group. The experimental results demonstrated that the changing in the crystal structure of $\mathrm{Ca}_{2-x} \mathrm{Cu}_{x} \mathrm{P}_{2} \mathrm{O}_{7}$ (i.e., bond angle of $\mathrm{P}-\mathrm{O}-\mathrm{P}$ in $\mathrm{P}_{2} \mathrm{O}_{7}{ }^{4-}$ and distortion phenomena in $\mathrm{M}-\mathrm{O}_{6}$ octahedral site) can cause the correlation between the dielectric and optical properties of the sample.

\section{Introduction}

Nowadays, the metal phosphate materials show the interesting properties because they were used in wide applications. For example, they have been applied as microwave dielectric materials, corrosion-resistant coatings, biomedical cements, chelating agents, glass ceramics, and high-quality fertilizers ${ }^{1-3}$. Bian et al. ${ }^{2}$ reported that the metal pyrophosphates $\left(\mathrm{M}_{2} \mathrm{P}_{2} \mathrm{O}_{7}, M=\right.$ divalent cations) show the low-loss dielectric properties as well as a relatively low sintering temperature. The $M_{2} \mathrm{P}_{2} \mathrm{O}_{7}$ compounds were also observed that when the ionic radius of $M$ in the $M_{2} \mathrm{P}_{2} \mathrm{O}_{7}$ structure is higher than $0.97 \AA\left(M=\mathrm{Ca}^{2+}, \mathrm{Sr}^{2+}, \mathrm{Ba}^{2+}, \mathrm{Pb}^{2+}\right.$, $\left.\mathrm{Cd}^{2+}\right)^{4}, \mathrm{M}_{2} \mathrm{P}_{2} \mathrm{O}_{7}$ compounds crystallize in the dichromate $\left(\mathrm{Cr}_{2} \mathrm{O}_{7}{ }^{2-}\right)$ form, in which a pair of $\mathrm{P}_{2} \mathrm{O}_{7}{ }^{4-}$ groups in eclipsed are the center of symmetry, and bridging oxygen $(0)$ atoms spreading to each other. However, when the ionic radius of $M$ is lower than $0.97 \AA\left(M=\mathrm{Ni}^{2+}, \mathrm{Mg}^{2+}, \mathrm{Zn}^{2+}, \mathrm{Co}^{2+}, \mathrm{Cu}^{2+}, \mathrm{Mn}^{2+}\right)$, the $\mathrm{M}_{2} \mathrm{P}_{2} \mathrm{O}_{7}$ structure is a thortveitite type ${ }^{5}$ (scandium yttrium silicate $(\mathrm{Sc}, \mathrm{Y})_{2} \mathrm{Si}_{2} \mathrm{O}_{7}$ with the crystal system of monoclinic, crystal class of prismatic $(2 / m)$, and space group of $\left.\mathrm{C} 2 / \mathrm{m}^{6}\right)$. Based on this thortveitite structure, $\mathrm{P}_{2} \mathrm{O}_{7}{ }^{4-}$ groups occur in staggered conformation. Moreover, comparing to the metal oxides (i.e., MO, $M=$ divalent metals), thortveitite-type pyrophosphates, such as $\alpha-\mathrm{Cu}_{2} \mathrm{P}_{2} \mathrm{O}_{7}$ and $\alpha-\mathrm{Mg}_{2} \mathrm{P}_{2} \mathrm{O}_{7}$, exhibit a rather low sintering temperature. However, the single metal pyrophosphate groups, such as $\mathrm{Cu}_{2} \mathrm{P}_{2} \mathrm{O}_{7}$, $\mathrm{Mg}_{2} \mathrm{P}_{2} \mathrm{O}_{7}, \mathrm{Zn}_{2} \mathrm{P}_{2} \mathrm{O}_{7}$, and $\mathrm{Co}_{2} \mathrm{P}_{2} \mathrm{O}_{7}$, still show the phase transition with changing sintering temperature. 
Therefore, the first aim of this research is to modify the crystal structures of some metal pyrophosphate compounds in order to decrease the loss of the dielectric value, manipulate the relative permittivity with variation temperatures, and improve the stability of the crystal structure at high temperature range.

The crystal structures of $\mathrm{M}_{2} \mathrm{P}_{2} \mathrm{O}_{7}$ compounds have been extensively investigated, and some metal pyrophosphates exhibit the allotropic property (a property of some compounds to exist in two or higher two crystal forms). For example, the $\beta-\mathrm{Ca}_{2} \mathrm{P}_{2} \mathrm{O}_{7}$ is tetragonal, whereas $a-\mathrm{Ca}_{2} \mathrm{P}_{2} \mathrm{O}_{7}$ is monoclinic ${ }^{7} . \mathrm{Ca}_{2} \mathrm{P}_{2} \mathrm{O}_{7}$ is also an important material in the fields of luminescence ${ }^{8}$ and biomaterials ${ }^{9}$. The thortveitite form undergoes a reversible phase transformation below $600^{\circ} \mathrm{C}$ from $a$-form (occurred at low temperature) to the $\beta$-form (occurred at high temperature). Whereas the dichromate form undergoes irreversible transformation at temperatures above $700^{\circ} \mathrm{C}$. The thortveitite-form $\mathrm{M}_{2} \mathrm{P}_{2} \mathrm{O}_{7}\left(\mathrm{M} \mathrm{Mg}^{2+}, \mathrm{Mn}^{2+}\right.$, and $\left.\mathrm{Zn}^{2+}\right)$ compounds are difficult to sinter into dense ceramics ${ }^{5}$. $\mathrm{SrZnP}_{2} \mathrm{O}_{7}, \mathrm{CaZnP}_{2} \mathrm{O}_{7}, a-\mathrm{Zn}_{2} \mathrm{P}_{2} \mathrm{O}_{7}, \mathrm{SrCuP}_{2} \mathrm{O}_{7}, \mathrm{Mn}_{2} \mathrm{P}_{2} \mathrm{O}_{7}$, and $\mathrm{CaCuP}_{2} \mathrm{O}_{7}$ are the effective glass-free low temperature cofired ceramic (LTCC) materials ${ }^{2,10,11}$. All these metal pyrophosphates react with silver $(\mathrm{Ag})$, but $\mathrm{CaZnP}_{2} \mathrm{O}_{7}$ and $\mathrm{SrZnP}_{2} \mathrm{O}_{7}$ do not react with copper $(\mathrm{Cu})^{5}$.

Unary metal pyrophosphate, such as $\mathrm{Mg}_{2} \mathrm{P}_{2} \mathrm{O}_{7}$ was thermally synthesized by using the minerals, such as dittmarite $\left(\mathrm{NH}_{4} \mathrm{MgPO}_{4} \cdot \mathrm{H}_{2} \mathrm{O}\right)$, struvite $\left(\mathrm{NH}_{4} \mathrm{MgPO}_{4} \cdot 6 \mathrm{H}_{2} \mathrm{O}\right)$, and newberyite $\left(\mathrm{MgHPO}_{4} \cdot 3 \mathrm{H}_{2} \mathrm{O}\right)$, as the precursors ${ }^{12}$. Binary metal pyrophosphates, such as $\mathrm{Mn}_{1.8} \mathrm{Co}_{0.2} \mathrm{P}_{2} \mathrm{O}_{7}$ was synthesized from the thermal decomposition of manganese cobalt hydrogen phosphate trihydrate $\left(\mathrm{Mn}_{0.9} \mathrm{Co}_{0.1} \mathrm{HPO}_{4} \cdot 3 \mathrm{H}_{2} \mathrm{O}\right){ }^{13}$. Another binary metal compound, $\mathrm{CaCuP}_{2} \mathrm{O}_{7}$, was synthesized by using a mixture of diammonium hydrogen phosphate $\left(\left(\mathrm{NH}_{4}\right)_{2} \mathrm{HPO}_{4}\right)$, calcium carbonate $\left(\mathrm{CaCO}_{3}\right)$, and copper oxide $(\mathrm{CuO})$ with the losses of carbon dioxide $\left(\mathrm{CO}_{2}\right)$ and ammonia $\left(\mathrm{NH}_{3}\right)$ gasses based on the following equation (Eq. (1)) ${ }^{14}$.

$2\left(\mathrm{NH}_{4}\right)_{2} \mathrm{HPO}_{4}(\mathrm{~s})+\mathrm{CaCO}_{3}(\mathrm{~s})+\mathrm{CuO}(\mathrm{s}) \rightarrow \mathrm{CaCuP}_{2} \mathrm{O}_{7}(\mathrm{~s})+3 \mathrm{H}_{2} \mathrm{O}(\mathrm{g})+4 \mathrm{NH}_{3}(\mathrm{~g})+\mathrm{CO}_{2}(\mathrm{~g})(1)$

To decompose the carbonate $\left(\mathrm{CO}_{3}{ }^{2-}\right)$ and to condense the phosphate $\left(\mathrm{PO}_{4}{ }^{3-}\right)$, resulting in the formation of pyrophosphate $\left(\mathrm{P}_{2} \mathrm{O}_{7}{ }^{4-}\right)$, the solid-state starting materials $\left(\left(\mathrm{NH}_{4}\right)_{2} \mathrm{HPO}_{4}+\mathrm{CaCO}_{3}+\mathrm{CuO}\right)$ were homogeneously mixed first and kept at $700^{\circ} \mathrm{C}$. The obtained mixture was ground and then kept at $1060^{\circ} \mathrm{C}$ for nine days. Using this thermal decomposition reaction, $\mathrm{CaCuP}_{2} \mathrm{O}_{7}$ was successfully synthesized. In addition, manganese cobalt magnesium hydrogen phosphate trihydrate $\left(\mathrm{Mn}_{0.90} \mathrm{Co}_{0.05} \mathrm{Mg}_{0.05} \mathrm{HPO}_{4} \cdot 3 \mathrm{H}_{2} \mathrm{O}\right)$ ${ }^{15}$, manganese cobalt magnesium pyrophosphate dihydrate $\left(\mathrm{Mn}_{1.8} \mathrm{Co}_{0.1} \mathrm{Mg}_{0.1} \mathrm{P}_{2} \mathrm{O}_{7} \cdot 2 \mathrm{H}_{2} \mathrm{O}\right){ }^{16}$, and ammonium cobalt zinc manganese monohydrate $\left(\mathrm{NH}_{4} \mathrm{Co}_{0.8} \mathrm{Zn}_{0.1} \mathrm{Mn}_{0.1} \mathrm{PO} 4 \cdot \mathrm{H} 2 \mathrm{O}\right){ }^{17}$ were employed as the precursors to synthesize the ternary metal pyrophosphates, namely $\mathrm{Mn}_{1.8} \mathrm{Co}_{0.1} \mathrm{Mg}_{0.1} \mathrm{P}_{2} \mathrm{O}_{7}$, $\mathrm{Mn}_{1.8} \mathrm{Co}_{0.1} \mathrm{Mg}_{0.1} \mathrm{P}_{2} \mathrm{O}_{7}$, and $\mathrm{Co}_{1.6} \mathrm{Zn}_{0.2} \mathrm{Mn}_{0.2} \mathrm{P}_{2} \mathrm{O}_{7}$, respectively.

Most studies of different metal phosphate and metal pyrophosphate compounds have focused on both the syntheses and the characterizations of bulk ${ }^{18,19}$ and nano particles ${ }^{20,21}$, kinetics and thermodynamics of the reaction ${ }^{22,23}$, and their properties ${ }^{24,25}$. For example, the photoluminescence of the $\mathrm{LiMg}_{0.74} \mathrm{Mn}_{0.26} \mathrm{PO}_{4}$ phosphor was investigated and the results revealed that the luminescent property of this phosphor 
depended on its surface area ${ }^{26}$. Nevertheless, the study of relationship between crystal structures and dielectric properties is not widely understand. Therefore, the second aim of this work is to investigate probe the influence of the crystal structure on the dielectric phenomena of binary metal pyrophosphate compounds. Furthermore, substitutional solid solutions (binary metal compounds) based on the HumeRothery rules can be formed if the solute $\left(\mathrm{Ca}^{2+}\right)$ and solvent $\left(\mathrm{Cu}^{2+}\right.$ of $\left.\mathrm{Cu}_{2} \mathrm{P}_{2} \mathrm{O}_{7}\right)$ have similar valency $(\mathrm{Cu}=$ $\mathrm{Ca}=2+)$, and same crystal structure $\left(\beta-\mathrm{Cu}_{2} \mathrm{P}_{2} \mathrm{O}_{7}=\alpha-\mathrm{Ca}_{2} \mathrm{P}_{2} \mathrm{O}_{7}=\right.$ monoclinic). These information show a high possibility of substitutional metals between $\mathrm{Cu}$ and $\mathrm{Ca}$ ions to form binary metal solid solution in pyrophosphate compounds, i.e., $\mathrm{Ca}_{2-x} \mathrm{Cu}_{x} \mathrm{P}_{2} \mathrm{O}_{7}$.

Dielectric properties of the metal pyrophosphates occur due to two effects. They comprise the movement of $\mathrm{M}^{2+}$ ions in the $\mathrm{MO}_{6}$ octahedral and the shifting of $\mathrm{O}$ atoms in the collinear $\mathrm{P}-\mathrm{O}-\mathrm{P}$ bridge of $\mathrm{O}_{3} \mathrm{P}-\mathrm{O}-\mathrm{PO}_{3}$ or $\mathrm{P}_{2} \mathrm{O}_{7}{ }^{4-}$ anion. If the collinear $\mathrm{P}-\mathrm{O}-\mathrm{P}$ bond of the $\mathrm{P}_{2} \mathrm{O}_{7}{ }^{4-}$ is destroyed, $\mathrm{MO}_{6}$ octahedral will also occur some distortions. This phenomena will improve the dielectric properties of materials by the polarization production ${ }^{27}$. It is well known that the highly relative permittivity of $\mathrm{BaTiO}_{3}$ tetragonal perovskite occurring from $\mathrm{Ti}^{4+}$ ion off-centered in $\mathrm{TiO}_{6}$ octahedral.

The atomic radii of $\mathrm{Cu}^{2+}$ and $\mathrm{Ca}^{2+}$ are 0.73 and $1.00 \AA$, whereas their electronegativities are 1.90 and 1.00 , respectively ${ }^{28}$. By doping the large cationic species, i.e., $\mathrm{Ca}^{2+}$, in the crystal structure of $\mathrm{Cu}_{2} \mathrm{P}_{2} \mathrm{O}_{7}$ host, resulting in the formation of $\mathrm{Ca}_{2-x} \mathrm{Cu}_{x} \mathrm{P}_{2} \mathrm{O}_{7}$ solid solutions. Both the distortion the $\mathrm{MO}_{6}$ octahedral and the $\mathrm{O}$ shifting in the collinear $\mathrm{P}-\mathrm{O}-\mathrm{P}$ bond phenomena may be occurred. These phenomena may then improve the dielectric properties of $\mathrm{Ca}^{2+}$-doped $\mathrm{Cu}_{2} \mathrm{P}_{2} \mathrm{O}_{7}$ compounds at low sintering temperature. Consequently, to investigate this doubt, this research synthesized $\mathrm{Ca}_{2-x} \mathrm{Cu}_{x} \mathrm{P}_{2} \mathrm{O}_{7}(x=0.00-2.00)$ by using the conventional and uncomplicated methods. After that, various scientific methods were then used to characterize and confirm the synthesized $\mathrm{Ca}_{2-x} \mathrm{Cu}_{x} \mathrm{P}_{2} \mathrm{O}_{7}$ samples. The Raman and Fourier transform infrared (FTIR) spectrophotometers were employed to characterize the vibrational spectroscopy of the synthesized samples. X-ray diffraction (XRD) technique was used to investigate the crystal structure of samples. The dielectric property of the samples were also investigated by using a LCR meter, an effective technique for the material measurement. The polarization phenomena in the crystal structure of samples were studied in order to characterize bond length and bond angle of $\mathrm{Ca}_{2-x} \mathrm{Cu}_{x} \mathrm{P}_{2} \mathrm{O}_{7}$. The chromaticity property was studied by applying the image sensor with a spatially multiplexed exposure-high dynamic range (SME-HDR) imaging function. The results were then compared to the CIE (International Commission on Illumination) chromaticity diagram (standard database). Consequently, these synthesized $\mathrm{Ca}_{2-x} \mathrm{Cu}_{x} \mathrm{P}_{2} \mathrm{O}_{7}$ compounds can be then applied as an effective optical material. In addition, the synchrotron light technology was also employed to analyze the $\mathrm{Ca}_{2-} \mathrm{Cu}_{x} \mathrm{P}_{2} \mathrm{O}_{7}$ samples by using the $\mathrm{X}$-ray absorption spectroscopic (XAS) mode at the $\mathrm{Cu}$ and $\mathrm{Ca} \mathrm{K}$-edge.

\section{Methods}

\section{Preparation.}


Binary metal pyrophosphate samples with various $\mathrm{Ca} / \mathrm{Cu}$ ratios $\left(\mathrm{Ca}_{2-x} \mathrm{Cu}_{x} \mathrm{P}_{2} \mathrm{O}_{7}, x=0.00,0.50,1.00,1.50\right.$, and 2.00) were synthesized via the solid-state thermal decomposition method. To avoid the contamination, the high-purity starting materials, namely $\left(\mathrm{NH}_{4}\right)_{2} \mathrm{HPO}_{4}(99 \%), \mathrm{CuO}(99.9 \%)$, and calcium oxide (CaO, 99.9\%) were selected in this preparation process. All starting materials were weighted according to the stoichiometric ingredients and then homogenized by vibratory milling with $10 \mathrm{~mm}$ spherical yttria (yttrium oxide, $\mathrm{Y}_{2} \mathrm{O}_{3}$ ) stabilized zirconia (zirconium dioxide, $\mathrm{ZrO}_{2}$ ) ( $\mathrm{YSZ}$ ) grinding beads in ethanol media for $4 \mathrm{~h}$. The dried powders were transferred to crucibles and directly heated at $1000^{\circ} \mathrm{C}$ for $24 \mathrm{~h}$ for the $\mathrm{Ca}_{2-x} \mathrm{Cu}_{x} \mathrm{P}_{2} \mathrm{O}_{7}$, when $x=0.00-1.50$, and $800^{\circ} \mathrm{C}$ for $24 \mathrm{~h}$ for a $\mathrm{Ca}_{2-x} \mathrm{Cu}_{x} \mathrm{P}_{2} \mathrm{O}_{7}$, when $x=2.00$. After that, the

calcined powders were ball-milled anew, pressed uniaxial into small pellets at the pressure of $1000 \mathrm{~kg} \cdot \mathrm{cm}^{-2}$ and then sintered at $950^{\circ} \mathrm{C}$ for $24 \mathrm{~h}$ for the $\mathrm{Ca}_{2-x} \mathrm{Cu}_{x} \mathrm{P}_{2} \mathrm{O}_{7}$, when $x=0.00-1.50$, and $1030^{\circ} \mathrm{C}$ for $24 \mathrm{~h}$ for a $\mathrm{Ca}_{2-x} \mathrm{Cu}_{x} \mathrm{P}_{2} \mathrm{O}_{7}$, when $x=2.00$. The observed densities of all prepared metal pyrophosphates, in theory, were investigated by Archimedes' principle and found in the range of 95-98\% (Fig. 1). The preparation of the target powder samples $\left(\mathrm{Ca}_{2-x} \mathrm{Cu}_{x} \mathrm{P}_{2} \mathrm{O}_{7}\right)$ were carried out according to the following reaction (Eq. (2)),

$x \mathrm{CuO}(\mathrm{s})+(2-x) \mathrm{CaO}(\mathrm{s})+2\left(\mathrm{NH}_{4}\right)_{2} \mathrm{HPO}_{4}(\mathrm{~s}) \rightarrow \mathrm{Ca}_{2-x} \mathrm{Cu}_{x} \mathrm{P}_{2} \mathrm{O}_{7}(\mathrm{~s})+4 \mathrm{NH}_{3}(\mathrm{~g})+3 \mathrm{H}_{2} \mathrm{O}(\mathrm{g})(2)$

where $x=0.00-2.00$.

\section{Characterization.}

The room temperature FTIR spectra of the samples were recorded by using a Perkin Elmer Spectrum GX FTIR spectrometer. The measured wavenumber range is of $4000-400 \mathrm{~cm}^{-1}$, whereas the selected scan number and resolution were 8 scans and $4 \mathrm{~cm}^{-1}$, respectively. A thermo scientific DXR Raman microscope were used to record the Raman spectra in the Raman shift of $1300-100 \mathrm{~cm}^{-1}$ using the scan number of 8 scans. A Raman spectrum was observed by irradiating each synthesized sample with an intense beam of an argon ion ( $\mathrm{Ar}^{+}$) laser having a wavenumber of $20492 \mathrm{~cm}^{-1}$ (wavelength of $488 \mathrm{~nm}$ ). The power of the incident beam was $12.5 \mathrm{~mW}$. The XRD patterns of all prepared samples were recorded by using a D8 Advance X-ray diffractometer (XRD, Bruker AXS, Karlsruhe, Germany) with Cu K ${ }_{a}$ radiation $(\lambda=0.1546 \mathrm{~nm})$ to analyze and confirm the crystal structures of samples. The dielectric properties were analyzed as a function of the frequency $(1-1000 \mathrm{kHz})$ and temperature (room temperature to $150^{\circ} \mathrm{C}$ ) using an Agilent / HP 4284A precision LCR meter (an effective technique for the material measurement with the wide frequency range $(20 \mathrm{~Hz}-1 \mathrm{MHz})$ and superior signal performance to test materials to the most commonlyused test standards). The Sony IMX214 CMOS image sensor (CIS, 13 MP "stacked" CIS with a spatially multiplexed exposure-high dynamic range (SME-HDR) imaging function) was applied to focus the colors of the samples. The results were then compared to the CIE (International Commission on Illumination) chromaticity diagram (standard database) to estimate the trend of the absorption wavelength. The X-ray absorption spectroscopy (XAS) was operated at the Beamline 8 (BL8) Station of the National Synchrotron Research Center (NSRC, Nakhon Ratchasima, Thailand). BL8 of the NSRC is routinely operated for the XAS in an intermediate photon energy range from 1.25 to $10 \mathrm{keV}^{29}$. The double crystal $\mathrm{Ge}(220)$ was used for the extended X-ray absorption fine structure (EXAFS) monochromator. The XAS spectra were detected on transmission mode at the copper (Cu) and calcium (Ca) K-edge. 


\section{Results And Discussion}

\section{Structural, optical, and dielectrically analyses.}

After applying the D8 Advance X-ray diffractometer, the resulting XRD patterns of the synthesized $\mathrm{Ca}_{2-x} \mathrm{Cu}_{x} \mathrm{P}_{2} \mathrm{O}_{7}$ powders $(x=0.00-2.00)$ are displayed in Fig. 2. The structures of $\mathrm{Ca}_{2-x} \mathrm{Cu}_{x} \mathrm{P}_{2} \mathrm{O}_{7}$ were analyzed through the Rietveld refinement analytic technique ${ }^{30}$ using the FullProf package ${ }^{31}$. A pseudoVoigt function (a linear combination between the Lorentzian and the Gaussian functions) was adequate at all time for obtaining the good fits of the experimental data. The initial model for the refinement of the single phase structure $\left(\mathrm{Ca}_{2} \mathrm{P}_{2} \mathrm{O}_{7}\right.$ and $\left.\mathrm{Cu}_{2} \mathrm{P}_{2} \mathrm{O}_{7}\right)$ was took from parameters described well in the Calvo research ${ }^{32}$.

In addition, Fig. 3 showed the corresponding Rietveld refinement results of the $\mathrm{Ca}_{2-x} \mathrm{Cu}_{x} \mathrm{P}_{2} \mathrm{O}_{7}$, when $x=0.00,1.00$, and 2.00. Fig. 3 showed the calculated $\left(\mathrm{Y}_{\text {cal }}\right)$ and observed $\left(\mathrm{Y}_{\mathrm{obs}}\right)$ diffraction patterns as well as the different values between them $\left(Y_{\mathrm{obs}}-\mathrm{Y}_{\mathrm{cal}}\right)$ of samples. The refinement plots gave the evolution of the XRD patterns in the various ratios between $\mathrm{Ca}$ and $\mathrm{Cu}\left(\mathrm{Ca}_{2-x} \mathrm{Cu}_{x} \mathrm{P}_{2} \mathrm{O}_{7}, x=0.00,1.00\right.$ and 2.00). The Rietveld refinement analysis and the XRD data of powders confirmed the formation of metal pyrophosphate compounds $\left(\mathrm{Ca}_{2-x} \mathrm{Cu}_{x} \mathrm{P}_{2} \mathrm{O}_{7}\right)$.

The crystallographic information of the synthesized compounds was described briefly. When $x=0.00$, the single metal pyrophosphate phase, $\beta-\mathrm{Ca}_{2} \mathrm{P}_{2} \mathrm{O}_{7}$, was obtained with the tetragonal crystal system, space group of $P 4_{1}$, space group number of 76 , Schoenflies symbol of $C_{4}{ }^{2}{ }^{33}$, and number of formula units per unit cell or $Z=8$. When $x=1.00$, the binary metal pyrophosphate phase, $\mathrm{CaCuP}_{2} \mathrm{O}_{7}$, was obtained with the monoclinic crystal system, space group of $P{ }_{1} / C$, space group number of 14 , Schoenflies symbol of $C_{2}{ }^{5}$, and $Z=4$. Finally, when $x=2.00$, another single metal pyrophosphate phase, $a-\mathrm{Cu}_{2} \mathrm{P}_{2} \mathrm{O}_{7}$, was obtained with the monoclinic crystal system, space group of $C 2 / C$, space group number of 15 , Schoenflies symbol of $C_{2 h^{6}}{ }^{6}$, and $Z=4$. For other $\mathrm{Ca}_{2-x} \mathrm{Cu}_{x} \mathrm{P}_{2} \mathrm{O}_{7}$ samples, when $x=0.50$, exhibited two phases between $\mathrm{CuCaP}_{2} \mathrm{O}_{7}$ and $\alpha$ $\mathrm{Cu}_{2} \mathrm{P}_{2} \mathrm{O}_{7}$, whereas, when $x=1.50$, two phases between $\mathrm{CuCaP}_{2} \mathrm{O}_{7}$ and $\beta-\mathrm{Ca}_{2} \mathrm{P}_{2} \mathrm{O}_{7}$ were then observed. The $\mathrm{P}-\mathrm{O}-\mathrm{P}$ bond angles (of the $\mathrm{O}_{3} \mathrm{P}-\mathrm{O}-\mathrm{PO}_{3}$ bridge of $\mathrm{P}_{2} \mathrm{O}_{7}{ }^{4-}$ ) and $M-\mathrm{O}_{6}$ bond lengths $(M=\mathrm{Ca}$ or $\mathrm{Cu}$ ) were determined by using the refinement analysis, and the obtained values were summarized in Table 1.

Table 1. Bond angles and bond lengths from the Rietveld refinement analytic technique for the synthesized $\mathrm{Ca}_{2-x} \mathrm{Cu}_{x} \mathrm{P}_{2} \mathrm{O}_{7}$ samples; $x=0.00,1.00$, and 2.00 


\begin{tabular}{|c|c|c|c|c|c|c|c|c|}
\hline & & & Bonding & $\begin{array}{l}\text { Sample } \\
1\end{array}$ & $\begin{array}{l}\text { Sample } \\
2\end{array}$ & $\begin{array}{l}\text { Sample } \\
3\end{array}$ & $\begin{array}{l}\text { Sample } \\
4\end{array}$ & \\
\hline \multirow[t]{6}{*}{2.00} & $a-\mathrm{Cu}_{2} \mathrm{P}_{2} \mathrm{O}_{7}$ & $154.60(10)$ & $\mathrm{Cu}-\mathrm{O}_{\mathrm{eq}}$ & $1.886(5)$ & ND & ND & ND & 1.2 \\
\hline & & & $\mathrm{Cu}-\mathrm{O}_{\text {eq }}$ & $1.942(6)$ & ND & ND & ND & \\
\hline & & & $\mathrm{Cu}-\mathrm{O}_{\text {eq }}$ & $1.980(5)$ & ND & ND & ND & \\
\hline & & & $\mathrm{Cu}-\mathrm{O}_{\mathrm{eq}}$ & $1.995(5)$ & ND & ND & ND & \\
\hline & & & $\mathrm{Cu}-\mathrm{O}_{\mathrm{ax}}$ & $2.354(9)$ & ND & ND & ND & \\
\hline & & & $\mathrm{Cu}-\mathrm{O}_{\mathrm{ax}}$ & $2.920(9)$ & ND & ND & ND & \\
\hline \multirow[t]{6}{*}{1.00} & $\mathrm{CaCuP}_{2} \mathrm{O}_{7}$ & $159.00(1)$ & $\mathrm{Cu}-\mathrm{O}_{\mathrm{eq}}$ & $1.853(3)$ & ND & ND & ND & 2.86 \\
\hline & & & $\mathrm{Cu}-\mathrm{O}_{\mathrm{eq}}$ & $2.004(2)$ & ND & ND & ND & \\
\hline & & & $\mathrm{Cu}-\mathrm{O}_{\text {eq }}$ & $2.106(1)$ & ND & ND & ND & \\
\hline & & & $\mathrm{Cu}-\mathrm{O}_{\mathrm{eq}}$ & $2.129(5)$ & ND & ND & ND & \\
\hline & & & $\mathrm{Cu}-\mathrm{O}_{\mathrm{ax}}$ & $2.245(3)$ & ND & ND & ND & \\
\hline & & & $\mathrm{Cu}-\mathrm{O}_{\mathrm{ax}}$ & $2.811(1)$ & ND & ND & ND & \\
\hline \multirow[t]{7}{*}{0.00} & $\beta-\mathrm{Ca}_{2} \mathrm{P}_{2} \mathrm{O}_{7}$ & $116.51(7)$ & $\mathrm{Ca}-01$ & $2.53(5)$ & $2.52(6)$ & $2.55(4)$ & $2.49(5)$ & 1.31 \\
\hline & & $140.96(1)$ & $\mathrm{Ca}-\mathrm{O} 2$ & $2.33(4)$ & $2.60(5)$ & $2.65(6)$ & $2.19(4)$ & \\
\hline & & & $\mathrm{Ca}-\mathrm{O} 3$ & $2.50(5)$ & $2.89(4)$ & $2.61(5)$ & $2.36(5)$ & \\
\hline & & & $\mathrm{Ca}-\mathrm{O} 4$ & $2.80(7)$ & $2.16(6)$ & $2.26(10)$ & $2.56(7)$ & \\
\hline & & & $\mathrm{Ca}-\mathrm{O} 5$ & $2.36(4)$ & $2.27(4)$ & $2.26(4)$ & $2.28(4)$ & \\
\hline & & & $\mathrm{Ca}-\mathrm{O} 6$ & $2.18(6)$ & $2.30(4)$ & $2.34(5)$ & $2.53(5)$ & \\
\hline & & & $\mathrm{Ca}-\mathrm{O} 7$ & $2.91(4)$ & $2.83(5)$ & $2.50(4)$ & $2.81(5)$ & \\
\hline
\end{tabular}

when eq and ax subscripts are the equatorial and axial (or apical) positions, respectively, whereas the $\chi^{2}$ is goodness of fit. ND is not detected.

Since X-ray absorption near-edge structure (XANES) is very sensitive to both the change in the local geometry (especially the ligand environment of the metal) and the oxidation state ${ }^{34}$. Therefore, the spectra were collected at both $\mathrm{Ca}$ and $\mathrm{Cu} K$-edges. They could help to understand the Fourier transform evolutions 34 . The X-ray absorption edge energies $\left(E_{0}\right)$ of the synthesized $\mathrm{Ca}_{2-x} \mathrm{Cu}_{x} \mathrm{P}_{2} \mathrm{O}_{7}$ compounds at the $\mathrm{Ca}$ and $\mathrm{Cu}$ K-edge are listed in Table 2. 
Table 2. X-ray absorption edge energies $\left(E_{0}\right)$ of the synthesized $\mathrm{Ca}_{2-x} \mathrm{Cu}_{x} \mathrm{P}_{2} \mathrm{O}_{7}$ compounds, when $x=0.00-2.00$

\begin{tabular}{llll}
$\boldsymbol{x}$ values & Compounds & \multicolumn{2}{l}{ X-ray absorption edge energies $\left(E_{0}\right) /$ electron Volt, eV } \\
\cline { 3 - 4 } & & $\mathrm{Ca}$ Kedge & $\mathrm{Cu}$ Kedge \\
$\mathrm{Cu}^{0}$ & $\mathrm{Cu}^{0}$ & $\mathrm{ND}$ & 8978.45 \\
$\mathrm{Cu}^{1+}$ & $\mathrm{Cu}_{2} \mathrm{O}$ & $\mathrm{ND}$ & 8979.52 \\
\hline $\mathrm{Cu}^{2+}$ & $\mathrm{CuO}$ & $\mathrm{ND}$ & 8987.72 \\
\hline $\mathrm{Ca}^{2+}$ & $\mathrm{CaO}$ & 4033.09 & - \\
\hline 2.00 & $\mathrm{Cu}_{2} \mathrm{P}_{2} \mathrm{O}_{7}$ & $\mathrm{ND}$ & 8987.88 \\
\hline 1.50 & $\mathrm{Ca}_{0.5} \mathrm{Cu}_{1.5} \mathrm{P}_{2} \mathrm{O}_{7}$ & 4033.14 & 8987.08 \\
\hline 1.00 & $\mathrm{CaCuP}_{2} \mathrm{O}_{7}$ & 4033.42 & 8987.09 \\
\hline 0.50 & $\mathrm{Ca}_{1.5} \mathrm{Cu}_{0.5} \mathrm{P}_{2} \mathrm{O}_{7}$ & 4033.42 & 8987.13 \\
0.00 & $\mathrm{Ca}_{2} \mathrm{P}_{2} \mathrm{O}_{7}$ & $\mathrm{ND}$ & $\mathrm{ND}$ \\
\hline
\end{tabular}

ND is not detected.

The $E_{0}$ values of the various $\mathrm{Cu}$ valences $\left(\mathrm{Cu}^{0}, \mathrm{Cu}^{1+}\right.$, and $\left.\mathrm{Cu}^{2+}\right)$ obtained in this work are in line well to the information reported by Yano and Yachandra ${ }^{34}$. They reported that the $E_{0}$ values raise with raising oxidation state. They also described that an electron in an atom experiences the full charge of the positive nucleus. In contrast, in case of many electrons, the electrons in an outer layer are simultaneously repelled by the negative-charged electrons and attracted to the positive nucleus. The lower the oxidation state of metals, the less positive the overall charge of the atom. Consequently, to excite an electron from an orbital, more energy is required. In summary, when the metal has more positive charge, the $E_{0}$ values (XANES spectra) shifts to a higher energy ${ }^{34}$. According to Table 2, in the Cu $K$-edge, the $E_{0}$ values of the synthesized $\mathrm{Ca}_{2-x} \mathrm{Cu}_{x} \mathrm{P}_{2} \mathrm{O}_{7}$ samples $(x=0.50-2.00)$ were similar to the $E_{0}$ values of the $\mathrm{Cu}^{2+} 0$, pointing out that $\mathrm{Cu}^{2+}$ was in a monoclinic symmetry. In addition, the XANES spectra of samples in the Ca K-edge showed the $E_{0}$ values similar to $\mathrm{Ca}^{2+} \mathrm{O}$, indicating that there were $\mathrm{Ca}^{2+}$ in the crystal structure of $\mathrm{Cu}_{2} \mathrm{P}_{2} \mathrm{O}_{7}$ host, resulting in the formations of $\mathrm{Ca}_{2-x} \mathrm{Cu}_{x} \mathrm{P}_{2} \mathrm{O}_{7}$. Fig. 4 presented the local environment of $\mathrm{Ca}$ atoms when they entered the $\mathrm{Cu}_{2} \mathrm{P}_{2} \mathrm{O}_{7}$ structure. The spectra of $\mathrm{Ca}$ and $\mathrm{Cu}$ in $\mathrm{CuCaP}_{2} \mathrm{O}_{7}$ compound were difference. These demonstrated that the coordinated environments of the divalent $\mathrm{Ca}$ in the $\mathrm{CuCaP}_{2} \mathrm{O}_{7}$ are statistically significant difference 35 .

The coordinated complex with different properties have different colors such as blue for $\left.\mathrm{Cu}\left(\mathrm{NH}_{3}\right)_{4} \mathrm{H}_{2} \mathrm{O}\right)_{2}{ }^{2+}$, red for $\mathrm{Co}\left(\mathrm{NH}_{3}\right)_{5} \mathrm{H}_{2} \mathrm{O}^{3+}$, and green for $\mathrm{CoF}_{6}{ }^{3-}$. This different color phenomenon was well explained by the 
crystal field theory (CFT), that described by El Jazouli et al. and Chen et al. ${ }^{36,37}$. The optical properties and the corresponding $\mathrm{CIE}$ chromatic coordinates ${ }^{36,38,39}$ of $\mathrm{Ca}_{2-x} \mathrm{Cu}_{x} \mathrm{P}_{2} \mathrm{O}_{7}$ samples $(x=0.00-2.00)$ are showed in Fig. 5. All Ca/Cu ratio compounds, except the composition with $x=0.00\left(\mathrm{Ca}_{2} \mathrm{P}_{2} \mathrm{O}_{7}\right)$, showed a greenish color, in which $\mathrm{Ca}_{2} \mathrm{P}_{2} \mathrm{O}_{7}$ exhibited a colorless powder. The colors of samples were dictated from elongation or compression of the $z$ ligand bonds of $\mathrm{Cu}^{2+}$ ion. The result of composition with $x=2.00\left(\mathrm{Cu}_{2} \mathrm{P}_{2} \mathrm{O}_{7}\right)$ illustrated a yellowish-green color, while the binary metal compounds $(x=0.50-1.50)$ presented color tones that changed from blue-green to bluish-green.

The mean static atomic dielectric constants $\left(\varepsilon_{\mathrm{r}}\right)$ of the synthesized $\mathrm{Ca}_{2-x} \mathrm{Cu}_{x} \mathrm{P}_{2} \mathrm{O}_{7}$ compounds were estimated using the well-known Clausius-Mossotti relation ${ }^{40}$ as following equation (Eq. (3)):

$\varepsilon_{r}=\left(\frac{3 V_{m}+8 \pi \alpha_{D}}{3 V_{m}-4 \pi \alpha_{D}}\right)$

where $a_{\mathrm{D}}$ is the sum of the dielectric polarizabilities of individual ions, whereas $V_{\mathrm{m}}$ is the molar volume.

The effect of porosity on the permittivity was eliminated by applying the Bosman and Havinga's correction ${ }^{41}$ as showed in Eq. (4), which can be used for the some materials, i.e., dense ceramics, having porosity lower than $5 \%$ :

$\varepsilon_{\text {r'corrected }}=\varepsilon_{\text {r’measured }}(1+1.5 P)$

where $\varepsilon_{\mathrm{r}, \text { measured }}$ and $\varepsilon_{\mathrm{r}, \mathrm{corrected}}$ are the measured and corrected relative permittivity, respectively, and $P$ is fractional porosity.

After applying the Clausius-Mossotti relation (Eq. (3)), the dielectric constant $\left(\varepsilon_{\mathrm{r}}\right)$ values as a function of the composition $x$ of the synthesized $\mathrm{Ca}_{2-x} \mathrm{Cu}_{x} \mathrm{P}_{2} \mathrm{O}_{7}(x=0.00-2.00)$ were presented in Fig. 6 , which showed the combination values between the calculated data (atomic polarization part, red bars), and measured results (atomic polarization part + ionic polarization part, red and purple bars). The single metal pyrophosphates $\left(\mathrm{Ca}_{2} \mathrm{P}_{2} \mathrm{O}_{7}\right.$ and $\left.\mathrm{Cu}_{2} \mathrm{P}_{2} \mathrm{O}_{7}\right)$ showed the $\varepsilon_{\mathrm{r}}$ of 15.6 and 10.5 , which were higher than the $\varepsilon_{\mathrm{r}}$ of some binary metal pyrophosphates (i.e., $\mathrm{CaCuP}_{2} \mathrm{O}_{7}, \varepsilon_{\mathrm{r}}=9.8$ ), except other binary metal pyrophosphates of $x=0.50$ $\left(\mathrm{Ca}_{1.50} \mathrm{Cu}_{0.50} \mathrm{P}_{2} \mathrm{O}_{7}, \varepsilon_{\mathrm{r}}=11.6\right)$ and $1.50\left(\mathrm{Ca}_{0.50} \mathrm{Cu}_{1.50} \mathrm{P}_{2} \mathrm{O}_{7}, \varepsilon_{\mathrm{r}}=10.7\right)$. The Clausius-Mossotti equation focused on only the dielectric constant from atomic polarization (electron cloud bias in the electric fields). Indeed, the samples were measured at a frequency of $1 \mathrm{MHz}$ for the decreasing extrinsic factor, and the polarization caused the moving of both cations $\left(\mathrm{Cu}^{2+}, \mathrm{Ca}^{2+}\right.$, and $\left.\mathrm{P}^{5+}\right)$ and anions $\left(\mathrm{O}^{2-}\right)$ in the crystal $\mathrm{Ca}_{2-x} \mathrm{Cu}_{x} \mathrm{P}_{2} \mathrm{O}_{7}$ structure. The moving of the ions in the electric field were cause of increasing dielectric constant, which compared to the calculated data using the Clausius-Mossotti equation. The equation used in this study considered dielectric constant, using the bond angle, bond length, and volume of the $\mathrm{MO}_{6}$ octahedral. 
The extended X-ray absorption fine structure (EXAFS) spectra of the synthesized $\mathrm{Ca}_{2-x} \mathrm{Cu}_{x} \mathrm{P}_{2} \mathrm{O}_{7}$ samples are showed in Fig. 7. An environment around $\mathrm{Cu}$ atoms was investigated. The primitive EXAFS model was taking from parameters, which obtained from the Rietveld refinement of each sample.

Table 3. Bond length from EXAFS fitting for $\mathrm{Ca}_{2-x} \mathrm{Cu}_{x} \mathrm{P}_{2} \mathrm{O}_{7}$ samples; $x=1.00$ and 2.00

\begin{tabular}{|c|c|c|c|c|c|c|c|}
\hline $\mathrm{x}$ values & Compounds & Path & Shell & $\mathrm{CN}$ & $R / \AA$ & $\sigma^{2} / \AA^{2}$ & $R$-factor \\
\hline \multirow[t]{4}{*}{2.00} & \multirow[t]{4}{*}{$\mathrm{Cu}_{2} \mathrm{P}_{2} \mathrm{O}_{7}$} & $\mathrm{Cu}-\mathrm{O}_{\mathrm{eq}}$ & 1 & 2 & 1.90505 & 0.00508 & \multirow[t]{4}{*}{0.00369} \\
\hline & & $\mathrm{Cu}-\mathrm{O}_{\mathrm{eq}}$ & 1 & 2 & 1.96427 & 0.00499 & \\
\hline & & $\mathrm{Cu}-\mathrm{O}_{\mathrm{ax}}$ & 1 & 1 & 2.30075 & 0.03223 & \\
\hline & & $\mathrm{Cu}-\mathrm{O}_{\mathrm{ax}}$ & 2 & 1 & 2.91358 & 0.00796 & \\
\hline \multirow[t]{5}{*}{1.00} & \multirow[t]{5}{*}{$\mathrm{CaCuP}_{2} \mathrm{O}_{7}$} & $\mathrm{Cu}-\mathrm{O}_{\mathrm{eq}}$ & 1 & 1 & 1.88239 & 0.05892 & \multirow[t]{5}{*}{0.01308} \\
\hline & & $\mathrm{Cu}-\mathrm{O}_{\mathrm{eq}}$ & 1 & 2 & 1.94469 & 0.00529 & \\
\hline & & $\mathrm{Cu}-\mathrm{O}_{\mathrm{eq}}$ & 1 & 1 & 1.99797 & 0.06324 & \\
\hline & & $\mathrm{Cu}-\mathrm{O}_{\mathrm{ax}}$ & 1 & 1 & 2.15606 & 0.33359 & \\
\hline & & $\mathrm{Cu}-\mathrm{O}_{\mathrm{ax}}$ & 2 & 1 & 2.88853 & 0.00839 & \\
\hline
\end{tabular}

when eq and ax subscripts are equatorial and axial (or apical) positions, respectively. $\mathrm{CN}$ is coordination number, $R$ is radial distance, $\sigma^{2}$ is mean squared displacement, and $R$-factor is the fitting statistic factor.

Details of EXAFS spectroscopic fitting of $\mathrm{Ca}_{2-{ }_{-}} \mathrm{Cu}_{x} \mathrm{P}_{2} \mathrm{O}_{7}$ samples were summarized in Table 3 , which exhibited the distortion of $\mathrm{CuO}_{6}$ octahedral. The spectra of $x=0.00$ was undetectable because limitation of instrument in beamline 8 of the National Synchrotron Research Center (Thailand). As presented in Table 3, the samples, when $x=1.00$ and 2.00 , showed three main shells. The first shell of spectrum from the model

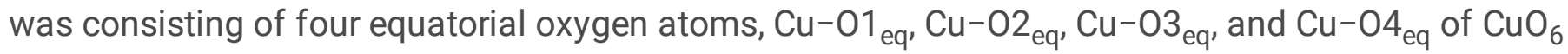
octahedral. Then, the second shell was detected only one axial oxygen atom, $\mathrm{Cu}-\mathrm{O} 5_{\mathrm{ax}}$. The last one axial oxygen atom, $\mathrm{Cu}-\mathrm{O6}_{\mathrm{ax}}$ was observed in the third shell. The $\mathrm{Cu}$ of $\mathrm{Cu}-\mathrm{O} 6$ were also combined to the phosphorus atom, $\mathrm{Cu}$-P. Different radial distances $(R / \AA)$ between the Rietveld refinement and EXAFS fitting may be cause of the measurement type of each technique. X-ray diffraction (Rietveld refinement) investigated the global structure, while X-ray absorption (EXAFS fitting) probed on the detail of $\mathrm{Cu} / \mathrm{Ca}$ local structure 42,43 . The fitting statistic factor ( $R$-factor) of $x=1.00$ were worse than that of $x=2.00$ because of two important factors. First, the crystal structure of $a-\mathrm{CaCuP}_{2} \mathrm{O}_{7}(x=1.00)$ was lower symmetry than another sample $\left(\mathrm{Cu}_{2} \mathrm{P}_{2} \mathrm{O}_{7}(x=1.00)\right)$. Second, the $\alpha-\mathrm{CaCuP}_{2} \mathrm{O}_{7}(x=1.00)$ exhibited four difference types of atomic position in the unit cell.

\section{Vibrational spectroscopy.}


The FTIR and Raman spectroscopies are good methods for identifying the chemical bonding of rotational, vibration, and other low-frequency modes in the phosphate group ${ }^{44}$. After applying the Spectrum $\mathrm{GX}$ FTIR spectrometer, the FTIR spectra of the synthesized $\mathrm{Ca}_{2-x} \mathrm{Cu}_{x} \mathrm{P}_{2} \mathrm{O}_{7}$ samples are presented in Fig. 8, whereas the corresponding assignments were tabulated in Table 4. The FTIR spectra observed in this research closely like to the spectral results reported in the literatures $12,13,15-17,45$. They successfully synthesized and investigated the vibrational spectroscopy of various single, double, and triple metal pyrophosphates, i.e., $\mathrm{Mg}_{2} \mathrm{P}_{2} \mathrm{O}_{7}, \mathrm{Mn}_{1.8} \mathrm{Co}_{0.2} \mathrm{P}_{2} \mathrm{O}_{7}, \mathrm{Mn}_{1.8} \mathrm{Co}_{0.1} \mathrm{Mg}_{0.1} \mathrm{P}_{2} \mathrm{O}_{7}, \mathrm{Co}_{1.6} \mathrm{Zn}_{0.2} \mathrm{Mn}_{0.2} \mathrm{P}_{2} \mathrm{O}_{7}$, and $\mathrm{CoFeP}_{2} \mathrm{O}_{7}$.

The vibrational characteristics of the synthesized $\mathrm{Ca}_{2-x} \mathrm{Cu}_{x} \mathrm{P}_{2} \mathrm{O}_{7}$ were described in detail. The strong vibrational bands at about 1190 and $1060 \mathrm{~cm}^{-1}$ were attributed to an asymmetric $\left(v_{a s} \mathrm{PO}_{3}\right)$ vibrational mode of $\mathrm{PO}_{3}$ unit of the pyrophosphate $\left(\mathrm{O}_{3} \mathrm{P}-\mathrm{O}-\mathrm{PO}_{3}{ }^{4-}\right.$ or $\left.\mathrm{P}_{2} \mathrm{O}_{7}{ }^{4-}\right)$ ions, whereas a vibrational band at about $1100 \mathrm{~cm}^{-1}$ was attributed to the symmetric stretching $\left(v_{\mathrm{s}} \mathrm{PO}_{3}\right)$ of the $\mathrm{PO}_{3}$ unit. The asymmetric $\left(\delta_{\text {as }}\right.$ $\left.\mathrm{PO}_{3}\right)$ and symmetric $\left(\delta_{\mathrm{S}} \mathrm{PO}_{3}\right)$ bending modes are observed at the vibrational positions at about 580 and $540 \mathrm{~cm}^{-1}$, respectively. The asymmetric $\left(v_{\mathrm{as}} \mathrm{P}-0-\mathrm{P}\right)$ and symmetric stretching $\left(v_{\mathrm{s}} \mathrm{P}-\mathrm{O}-\mathrm{P}\right)$ modes of the $\mathrm{P}-\mathrm{O}-\mathrm{P}$ bridge of the $\mathrm{O}_{3} \mathrm{P}-\mathrm{O}-\mathrm{PO}_{3}{ }^{4-}$ group were observed at the vibrational positions of about 960 and 740 $\mathrm{cm}^{-1}$, respectively. However, in case of the $\mathrm{Ca}_{2-x} \mathrm{Cu}_{x} \mathrm{P}_{2} \mathrm{O}_{7}$ samples with $x=0.50\left(\mathrm{Ca}_{1.5} \mathrm{Cu}_{0.5} \mathrm{P}_{2} \mathrm{O}_{7}\right)$ and $x=$ $1.5\left(\mathrm{Ca}_{0.5} \mathrm{Cu}_{1.5} \mathrm{P}_{2} \mathrm{O}_{7}\right)$, the $\mathrm{P}-\mathrm{O}-\mathrm{P}$ symmetric stretching mode appeared two peaks in the range of $776-693 \mathrm{~cm}^{-1}$, which corresponded to the vibrational characteristics (symmetric stretching) of the P-O-P bridge. These detected peaks may be due to the mixing phases of the metal pyrophosphate compounds, i.e., $\mathrm{Ca}_{2} \mathrm{P}_{2} \mathrm{O}_{7}$ and $\mathrm{CuCaP}_{2} \mathrm{O}_{7}$. In addition, the rocking mode of the $\mathrm{P}-\mathrm{O}-\mathrm{P}$ deformations, the torsional, and external modes were found in the $450-410 \mathrm{~cm}^{-1}$ regions.

The Raman spectroscopic technique was additionally applied to investigate and support the FTIR results, especially the vibrational spectroscopy of the metal oxide $(M-0)$ bond as well as the lattice vibration by observing at the low frequency range $\left(650-100 \mathrm{~cm}^{-1}\right)$. Furthermore, the phase characteristics $(\alpha$-, $\beta$-phases) of the metal pyrophosphate compounds can be observed from this spectroscopic technique. After applying the DXR Raman microscope, the Raman spectra of samples are shown in Fig. 9, and the corresponding vibrational assignments are listed in Table 4. It was observed that the result corresponded well to the FTIR result. The Raman results showed the specific phase, which formed at high temperature in the pyrophosphate with $x=1.00\left(\mathrm{CaCuP}_{2} \mathrm{O}_{7}\right)$ as described in the literature ${ }^{46}$ through undetectably weak peak at about $1210 \mathrm{~cm}^{-1}$. The three distinct peaks of the $\mathrm{Ca}_{2-x} \mathrm{Cu}_{x} \mathrm{P}_{2} \mathrm{O}_{7}$, where $x=0.00,0.50,1.50$ and 2.00 , that originated from the $v_{\mathrm{as}} \mathrm{PO}_{3}$ vibrational characteristics, were observed and found to be at about 1210,1140 and $1080 \mathrm{~cm}^{-1}$. The Raman spectra was clearly noticeable that the studied metal pyrophosphates displayed very sharpness and splitting, especially in the investigated frequency region $\left(1300-100 \mathrm{~cm}^{-1}\right)$. The vibrational analysis of the $\mathrm{P}_{2} \mathrm{O}_{7}{ }^{4-}$ ion, which contained the O-P-O radical $\left(\mathrm{PO}_{2}{ }^{-}\right.$of $\left.\mathrm{O}_{2} \mathrm{O}-\mathrm{P}-\mathrm{OPO}_{3}{ }^{4-}\right)$ and the $\mathrm{P}-\mathrm{O}-\mathrm{P}$ bride (of $\mathrm{O}_{3} \mathrm{P}-\mathrm{O}-\mathrm{PO}_{3}{ }^{4-}$ ) were exhibited in Raman spectra. Moreover, the $\mathrm{M}-\mathrm{O}$ stretching and the phase characteristics were also observed. The Raman spectra observed in this research were similar to the spectra reported by Sronsri et al. ${ }^{12,13,15-17}$ and Boonchom et al. ${ }^{45}$. The strong vibrational band around 
$1100 \mathrm{~cm}^{-1}$ was recognized to the stretching of the $\mathrm{PO}_{3}$ unit of the $\mathrm{O}_{3} \mathrm{P}-\mathrm{O}-\mathrm{PO}_{3}{ }^{4-}$. The asymmetric $\left(\mathrm{V}_{\text {asym }}\right.$ $\mathrm{POP})$ and symmetric $\left(v_{\text {sym }} \mathrm{POP}\right)$ stretching types of the $\mathrm{P}-\mathrm{O}-\mathrm{P}$ bridge of the $\mathrm{O}_{3} \mathrm{P}-\mathrm{O}-\mathrm{PO}_{3}{ }^{4-}$ were detected at about 960 and $730 \mathrm{~cm}^{-1}$, respectively. While the asymmetric $\left(\delta_{\text {asym }} \mathrm{PO}_{3}\right)$ and symmetric $\left(\delta_{\text {sym }} \mathrm{PO}_{3}\right)$ vibrational bending modes of the $\mathrm{O}_{3} \mathrm{P}-\mathrm{O}-\mathrm{PO}_{3}{ }^{4-}$ were observed at about 600 and $520 \mathrm{~cm}^{-1}$, respectively.

Table 4. Vibrational positions (wavenumber $/ \mathrm{cm}^{-1}$ ) and vibrational assignments (modes) of the synthesized $\mathrm{Ca}_{2-x} \mathrm{Cu}_{x} \mathrm{P}_{2} \mathrm{O}_{7}$ samples obtained from the FTIR and Raman techniques

\begin{tabular}{|c|c|c|c|c|}
\hline Compounds & Wavenumber $/ \mathrm{cm}^{-1}$ & FTIR & Raman & Assignments \\
\hline $\mathrm{Ca}_{2-x} \mathrm{Cu}_{x} \mathrm{P}_{2} \mathrm{O}_{7}$ & $1250-1200$ & NO & weak & $a$-phase characteristics \\
\hline \multirow{8}{*}{$x=0.00-2.00$} & $1200-1100$ & very strong & very strong & $v_{\text {as }} \mathrm{PO}_{3}$ \\
\hline & $1100-1050$ & very strong & very strong & $v_{\mathrm{s}} \mathrm{PO}_{3}$ \\
\hline & $1050-1000$ & very strong & very strong & $v_{\text {as }} \mathrm{PO}_{3}$ \\
\hline & $980-950$ & strong & very weak & $v_{\text {as }} \mathrm{P}-\mathrm{O}-\mathrm{P}$ \\
\hline & $760-730$ & medium & weak & $v_{\mathrm{s}} \mathrm{P}-\mathrm{O}-\mathrm{P}$ \\
\hline & $650-280$ & strong & strong & $\delta \mathrm{OPO}+v_{\mathrm{s}} M-O$ \\
\hline & $260-160$ & NO & weak & $v_{\mathrm{s}} M-0$ \\
\hline & $200-100$ & NO & medium & lattice vibration \\
\hline
\end{tabular}

NO is not observed.

\section{Dielectric and optical properties.}

\section{Structural-dielectric relation.}

Bond angle and bond length were successfully investigated by using the Rietveld refinement technique as shown in Table 1. The obtained refinement results were then used to describe the phenomena of the dielectric properties of samples. In general, the dielectric properties of the metal pyrophosphate $\left(\mathrm{M}_{2} \mathrm{P}_{2} \mathrm{O}_{7}\right)$ group occurred from two important effects, which consisted of O-atom shifting in the collinear $\mathrm{P}-\mathrm{O}-\mathrm{P}$ bridge, and $\mathrm{M}^{2+}$-ion movement in the $\mathrm{MO}_{6}$ octahedral. According to the previous works, due to the shifting of $\mathrm{O}$ atom in the collinear $\mathrm{P}-\mathrm{O}-\mathrm{P}$ bridge, the $\mathrm{P}-\mathrm{O}-\mathrm{P}$ bond angles of $\mathrm{Ca}_{2} \mathrm{P}_{2} \mathrm{O}_{7}$ and $\mathrm{Cu}_{2} \mathrm{P}_{2} \mathrm{O}_{7}$ of $130^{\circ} 47$ and $157^{\circ} 48$ were reported, respectively. In this section, only three synthesized $\mathrm{Ca}_{2-x} \mathrm{Cu}_{x} \mathrm{P}_{2} \mathrm{O}_{7}$ samples, when $x=$ $0.00,1.00$, and 2.00, were considered. The sample, when $x=0.00\left(\mathrm{Ca}_{2} \mathrm{P}_{2} \mathrm{O}_{7}\right)$, showed two different $\mathrm{P}-\mathrm{O}-\mathrm{P}$ bond angles. First, the bond angle of $116.52^{\circ}$ appeared for 4 clusters per a unit cell with the asymmetric $\mathrm{P}-\mathrm{O}$ bond lengths of $1.765 \AA$ and $1.887 \AA$. Second, the $\mathrm{P}-\mathrm{O}-\mathrm{P}$ bond angle of $140.96^{\circ}$ appeared for 4 clusters per unit cell with the symmetric $\mathrm{P}-\mathrm{O}$ bond lengths of $1.536 \AA$ and $1.827 \AA$. The sample, when $x=$ 
$2.00\left(\mathrm{Cu}_{2} \mathrm{P}_{2} \mathrm{O}_{7}\right)$, had a P-O-P bond angle of $154.6^{\circ}$, and appeared of 4 clusters per a unit cell with the symmetric $\mathrm{P}-\mathrm{O}$ bond length of $1.574 \AA$ A. Pogorzelec-Glaser et al. ${ }^{46}$ reported that at high temperature, the binary metal pyrophosphate $\left(\mathrm{CuM}^{2+} \mathrm{P}_{2} \mathrm{O}_{7}\right)$ compounds crystallized in the monoclinic crystal system with the space group of $C 2 / m$, and the $\mathrm{P}-\mathrm{O}-\mathrm{P}$ angle was linear $\left(180^{\circ}\right)$. The sample, when $x=1.00\left(\mathrm{CaCuP}_{2} \mathrm{O}_{7}\right)$, exhibited the space group of $P 2_{1} / n$. The refinement result showed the P-O-P bond angle of $159.00^{\circ}$ and appeared of 4 clusters per unit cell with asymmetric $\mathrm{P}-\mathrm{O}$ bond lengths of $1.592 \AA$ and $1.521 \AA$. However, the number of $\mathrm{P}-\mathrm{O}-\mathrm{P}$ clusters in each $\mathrm{Ca}_{2-x} \mathrm{Cu}_{x} \mathrm{P}_{2} \mathrm{O}_{7}$ sample $(x=0.00,1.00$, and 2.00) was equal (4). Based on these obtained results, the $\mathrm{P}-\mathrm{O}-\mathrm{P}$ cluster number did not affect the polarization of samples.

The single metal pyrophosphate, when $x=0.00\left(\mathrm{Ca}_{2} \mathrm{P}_{2} \mathrm{O}_{7}\right)$, showed outstanding the dielectric constant (15.6, as shown in Fig. 6). It was very high polarization; it therefore caused and made the narrow $\mathrm{P}-\mathrm{O}-\mathrm{P}$ bond angle. In addition, the long $\mathrm{P}-\mathrm{O}$ bond length of the sample of $x=0.00\left(\mathrm{Ca}_{2} \mathrm{P}_{2} \mathrm{O}_{7}\right)$, resulting in the weak bonding, was better polarization than the samples of $x=1.00\left(\mathrm{CaCuP}_{2} \mathrm{O}_{7}\right)$ and $x=2.00\left(\mathrm{Cu}_{2} \mathrm{P}_{2} \mathrm{O}_{7}\right)$. Additionally, the volume of the octahedral coordination was calculated using the method reported by Swanson et al. ${ }^{49}$ to present the relationship between the polarization and metal oxide bonding. Besides, the distortion index $(D)$ was used to describe the distortion of the sample crystal structure, Baur 50 described the calculation of $D$ value based on the bond lengths as shown in Eq. (5).

$D=\frac{1}{n} \sum_{i=1}^{n} \frac{\left|l_{i}-l_{a n}\right|}{l_{a n}}$

where $l_{\mathrm{av}}$ is the average bond length, and $l_{i}$ is the atomic distance from the central atom to the ith coordinating atom.

The refinement analysis results also showed the changing of the average $M-O$ bond lengths in the $M_{6}$ octahedral site, which caused the molecular polarization. As demonstrated in Table 5, both the average bond lengths and octahedral volumes decreased with increasing $x$ values. However, the different result was observed for the distortion index. The distortion index values increase with increasing $x$ values, which then decreased the molecular polarization, resulting in the decreasing of the dielectric constant $\left(\varepsilon_{\mathrm{r}}\right)$. These analyses showed that the polarization of the $\mathrm{Ca}_{2-x} \mathrm{Cu}_{x} \mathrm{P}_{2} \mathrm{O}_{7}$ occurred due to the $\mathrm{O}$ shifting in the collinear $\mathrm{P}-\mathrm{O}-\mathrm{P}$ bridge, which is the main factor of the generation of narrow bond angle that caused the high polarization and high dielectric constant. Moreover, the movement of $\mathrm{M}^{2+}$ ions in the $\mathrm{MO}_{6}$ octahedral was supplementary factor, in which the longer average $M-O$ bond length and larger octahedral volume, leading to the high polarization and high dielectric constant of the materials.

Table 5. Average bond length, octahedral volume, and distortion index of $\mathrm{Ca}_{2-x} \mathrm{Cu}_{x} \mathrm{P}_{2} \mathrm{O}_{7}$ samples $(x=0.00$, 1.00 , and 2.00) 


\begin{tabular}{lllll}
$\boldsymbol{x}$ values & Compounds & Average bond lengths / $\AA$ & Octahedral volumes / $\AA^{3}$ & Distortion index \\
\hline 2.00 & $\mathrm{Cu}_{2} \mathrm{P}_{2} \mathrm{O}_{7}$ & 2.1794 & 12.6198 & 0.1400 \\
\hline 1.00 & $\mathrm{CaCuP}_{2} \mathrm{O}_{7}$ & 2.4032 & 15.9050 & 0.0886 \\
\hline 0.00 & $\mathrm{Ca}_{2} \mathrm{P}_{2} \mathrm{O}_{7}$ & 2.4479 & 18.6696 & 0.0655
\end{tabular}

\section{Structural-optical relation.}

The distortion of the $\mathrm{MO}_{6}$ octahedral can increase the $\mathrm{Cu}-\mathrm{O}_{6}$ bond lengths of the $\mathrm{Ca}_{2-x} \mathrm{Cu}_{x} \mathrm{P}_{2} \mathrm{O}_{7}$, resulting in the increasing of octahedral crystal field splitting energy $\left(D_{0}\right.$, please see Fig. 10$)$. The $D_{0}$ values of the synthesized $\mathrm{Ca}_{2-x} \mathrm{Cu}_{x} \mathrm{P}_{2} \mathrm{O}_{7}$ samples $(x=0.50-2.00)$ are listed in Table 6.

Table 6. Approximate wavelength of the energy absorption

\begin{tabular}{|lllllll|}
\hline xvalues & Compounds & \multicolumn{2}{l}{ Wavelengths $/ \mathrm{nm}$} & \multirow{2}{*}{$\mathrm{D}_{0} / \mathrm{kJ}^{2} \cdot \mathrm{mol}^{-1}$} & \multicolumn{2}{c|}{$\mathrm{Cu}-\mathrm{O}_{\mathrm{ax}}$ bond lengths $/ \AA$} \\
& & Observed & Absorbed & & XRD & EXAFS \\
\hline 2.00 & $\mathrm{Cu}_{2} \mathrm{P}_{2} \mathrm{O}_{7}$ & 561 & 403 & 297 & 2.92 & 2.91 \\
\hline 1.50 & $\mathrm{Ca}_{0.5} \mathrm{Cu}_{1.5} \mathrm{P}_{2} \mathrm{O}_{7}$ & 488 & 642 & 186 & $\mathrm{ND}$ & $\mathrm{ND}$ \\
\hline 1.00 & $\mathrm{CaCuP}_{2} \mathrm{O}_{7}$ & 489 & 644 & 185 & 2.81 & 2.89 \\
\hline 0.50 & $\mathrm{Ca}_{1.5} \mathrm{Cu}_{0.5} \mathrm{P}_{2} \mathrm{O}_{7}$ & 492 & 648 & 184 & $\mathrm{ND}$ & $\mathrm{ND}$ \\
\hline 0.00 & $\mathrm{Ca}_{2} \mathrm{P}_{2} \mathrm{O}_{7}$ & $\mathrm{ND}$ & $\mathrm{ND}$ & $\mathrm{ND}$ & $\mathrm{ND}$ & $\mathrm{ND}$ \\
\hline
\end{tabular}

ND is not detected.

As presented in Table 6, the $\mathrm{D}_{0}$ increased with increasing of the $\mathrm{Cu}^{2+}$ fraction in the $\mathrm{Ca}_{2-x} \mathrm{Cu}_{x} \mathrm{P}_{2} \mathrm{O}_{7}$ compound, and when $x=2\left(\mathrm{Cu}_{2} \mathrm{P}_{2} \mathrm{O}_{7}\right)$, the highest $\mathrm{D}_{0}$ value was obtained. The compounds illustrated the change of color from blue-green to bluish-green. The colorless compound, when $x=0.00\left(\mathrm{Ca}_{2} \mathrm{P}_{2} \mathrm{O}_{7}\right)$, was due to the fulfillment state in the octet rule of $\mathrm{Ca}^{2+}$ ion in the structure, despite the distortion appearing in the $\mathrm{CaO}_{6}$ octahedral site. The octahedral splitting diagram of $\mathrm{Ca}_{2-x} \mathrm{Cu}_{x} \mathrm{P}_{2} \mathrm{O}_{7} ; x=0.50-2.00$ were summarized and presented in Fig. 10. Total interpretations showed that the $\mathrm{MO}_{6}$ octahedral distortion affected both color of the sample and the polarization of octahedral unit, as reflected on the dielectric constant of the compounds.

\section{Conclusion}

Binary metal pyrophosphates $\left(\mathrm{Ca}_{2-x} \mathrm{Cu}_{x} \mathrm{P}_{2} \mathrm{O}_{7}\right)$ were successfully synthesized via a thermal solid state reaction process. The synthesized $\mathrm{Ca}_{2-} \mathrm{Cu}_{x} \mathrm{P}_{2} \mathrm{O}_{7}$ samples were systematically characterized by various scientific instruments. The vibrational characteristics of the pyrophosphate $\left(\mathrm{P}_{2} \mathrm{O}_{7}{ }^{4-}\right)$ group were analyzed 
and confirmed by the Raman and FTIR spectroscopies. The crystal structures of samples were investigated by using the $X$-ray diffractometer. The experimental results exhibited that both the single $\left(\mathrm{Ca}_{2} \mathrm{P}_{2} \mathrm{O}_{7}\right.$, $\left.\mathrm{Cu}_{2} \mathrm{P}_{2} \mathrm{O}_{7}\right)$ and the mixing $\left(\mathrm{Ca}_{1.5} \mathrm{Cu}_{0.5} \mathrm{P}_{2} \mathrm{O}_{7}, \mathrm{CaCuP}_{2} \mathrm{O}_{7}, \mathrm{Ca}_{0.5} \mathrm{Cu}_{1.5} \mathrm{P}_{2} \mathrm{O}_{7}\right)$ metal pyrophosphate phases were obtained. The crystal structure of $\mathrm{Cu}_{2} \mathrm{P}_{2} \mathrm{O}_{7}$ with the space group of $\mathrm{P}_{4}$ was distorted, when the $\mathrm{Cu}^{2+}$-ion site was replaced by a bigger ionic radius, i.e., $\mathrm{Ca}^{2+}$ ion. When the ratio between $\mathrm{Ca}$ and $\mathrm{Cu}$ equal to 1.00 . The obtained binary metal pyrophosphate $\left(\mathrm{CuCaP}_{2} \mathrm{O}_{7}\right)$ showed the monoclinic crystal system with the space group of $P{ }_{1} / n$. Using the Rietveld refinement method, the bond angle of $\mathrm{P}-\mathrm{O}-\mathrm{P}$ bridge of $\mathrm{O}_{3} \mathrm{P}-\mathrm{O}-\mathrm{PO}_{3}{ }^{4-}$ (pyrophosphate) was calculated and found to be $159.0^{\circ}$. The dielectric properties of the synthesized $\mathrm{Ca}_{2-x} \mathrm{Cu}_{x} \mathrm{P}_{2} \mathrm{O}_{7}$ displayed two effects that comprised of the 0 -atom shifting in the collinear $\mathrm{P}-\mathrm{O}-\mathrm{P}$ bridge and $\mathrm{M}^{2+}$-ion movement in the $\mathrm{MO}_{6}$ octahedral. The experimental results also demonstrated that the $\mathrm{P}-\mathrm{O}-\mathrm{P}$ angle in $\mathrm{P}_{2} \mathrm{O}_{7}{ }^{4-}$ is the main factor that directly influenced the dielectric properties of the $\mathrm{Ca}_{2-x} \mathrm{Cu}_{x} \mathrm{P}_{2} \mathrm{O}_{7}$ samples. Narrow angle can also cause the higher polarization than that of wide angle. Finally, increasing the bond length of $\mathrm{Cu}-\mathrm{O}$ in the octahedral site of $\mathrm{CuO}_{6}$ can affect the sample color from blue-green to bluish-green. Consequently, these synthesized $\mathrm{Ca}_{2-x} \mathrm{Cu}_{x} \mathrm{P}_{2} \mathrm{O}_{7}$ compounds can be then applied as an effective material in an optical industrial.

\section{Declarations}

\section{Acknowledgements}

This work is supported by King Mongkut's Institute of Technology Ladkrabang [KREF146002]. The authors would like to thanks the Scientific Instruments Center KMITL for supporting TGA, FTIR, XRD, and SEM techniques.

\section{Author contributions statement}

R.B. carried out the experiments and analysis. B.B. designed the study, contributed in the experiments and analysis and wrote the main manuscript text. C.S. and S.T. contributed in characterization and analysis. K.C. contributed in the experiments and analysis and proved the main manuscript text. All the authors analyzed the results, contributed in discussion and to writing the manuscript.

\section{Competing interests}

The authors declare no competing interests.

\section{Additional information}

Correspondence and requests for materials should be addressed to B.B. or K.C.

\section{References}


1. Bian, J.; Kim D.; Hong K. Microwave dielectric properties of (Zn 1- x Mn x) 2 P 20 7. Journal of materials science $2005,40,1801-1803$.

2. Bian, J.-j.; Kim D.-W.; Hong K.S. Microwave Dielectric Properties of A2P2O7 (A= Ca, Sr, Ba; Mg, Zn, Mn). Japanese journal of applied physics 2004, 43, 3521.

3. Wenwei, W.; Yanjin F.; Xuehang W.; Sen L.; Shushu L. Preparation via solid-state reaction at room temperature and characterization of layered nanocrystalline NH4MnPO4 $\mathrm{H} 2 \mathrm{O}$. Journal of Physics and Chemistry of Solids 2009, 70, 584-587.

4. Weil, M.; Stöger B. Crystal chemistry of transition metal diarsenates M 2As 207 ( $M=M n, C o, N i, Z n)$ : Variants of the thortveitite structure. Acta Crystallographica Section B: Structural Science 2010, 66, 603-614.

5. Sebastian, M.T., Dielectric materials for wireless communication. 2010: Elsevier.

6. Chapman, R.; Mercer I.; Rankin A.; Spratt J. Thortveitite-a new gemstone. Gemmology 2004, 1.

7. Livitska, O.; Strutynska N.; Livitska O.; Slobodyanik N. The alternative approach to the preparation of complex calcium phosphates and their characterization. Functional materials 2017.

8. Ranby, P.; Mash D.; Henderson S. The investigation of new phosphors, with particular reference to the pyrophosphates. British Journal of Applied Physics 1955, 6, S18.

9. Lin, F.-H.; Liaw J.-R.; Hon M.-H.; Wang C.-Y. The effects of Na4P207· $10 \mathrm{H} 20$ addition on the mechanical properties of sintered Ca2P2O7 bioceramic. Materials chemistry and physics 1995, 41, 110-116.

10. Bian, J.; Kim D.; Hong K. Microwave dielectric properties of (Ca1- xZnx) 2P207. Materials Letters 2005, 59, 257-260.

11. Bian, J.-j.; Kim D.-W.; Hong K.S. Glass-free LTCC microwave dielectric ceramics. Materials research bulletin 2005, 40, 2120-2129.

12. Sronsri, C.; Sittipol W.; Kongpop U. Optimization of biodiesel production using magnesium pyrophosphate. Chemical Engineering Science 2020, 226, 115884.

13. Sronsri, C.; Noisong P.; Danvirutai C. Thermal decomposition kinetics of Mn 0.9 Co 0.1 HPO 4· 3H 2 O using experimental-model comparative and thermodynamic studies. Journal of Thermal Analysis and Calorimetry 2017, 127, 1983-1994.

14. Riou, D.; Goreaud M. CaCuP207: a structure closely related to a-Ca2P207. Acta Crystallographica Section C: Crystal Structure Communications 1990, 46, 1191-1193.

15. Sronsri, C.; Boonchom B. Thermal kinetic analysis of a complex process from a solid-state reaction by deconvolution procedure from a new calculation method and related thermodynamic functions of Mn0. 90Co0. 05Mg0. 05HPO4 3H2O. Transactions of Nonferrous Metals Society of China 2018, 28, 1887-1902.

16. Sronsri, C. Thermal dehydration kinetic mechanism of Mn1. 8Co0. 1Mg0. 1P2O7· 2H2O using Málek's equations and thermodynamic functions determination. Transactions of Nonferrous Metals Society of China 2018, 28, 1016-1026.

17. Sronsri, C.; Noisong P.; Danvirutai C. Isoconversional kinetic, mechanism and thermodynamic studies of the thermal decomposition of $\mathrm{NH} 4 \mathrm{Co} 0.8 \mathrm{Zn} 0.1 \mathrm{Mn} \mathrm{0.1} \mathrm{PO} 4 \cdot \mathrm{H} 2 \mathrm{O}$. Journal of Thermal Analysis 
and Calorimetry 2015, 120, 1689-1701.

18. Xiao, Z.W.; Hu G.R.; Peng Z.D.; Du K.; Gao X.G. Solid state synthesis and characterization of iron(II) pyrophosphate $\mathrm{Fe}_{2}$ P207. Chinese Chemical Letters 2007, 18, 1525-1527.

19. Bensalem, A.; Ahluwalia M.; Vijayaraghavan T.V.; Ko Y.H. Synthesis of amorphous MgHPO4 $x(\mathrm{R})[\mathrm{R}=$ Ethanol; Ethylene glycol] in anhydrous media. Materials Research Bulletin 1997, 32, 1473-1483.

20. Díaz, C.; Valenzuela M.L.; Lavayen V.; Mendoza K.; Pena D.; O’Dwyer C. Nanostructured copper oxides and phosphates from a new solid-state route. Inorganica Chimica Acta 2011, 377, 5-13.

21. Sronsri, C.; Danvirutai C.; Noisong P. Double function method for the confirmation of the reaction mechanism of LiCoPO 4 nanoparticle formation, reliable activation energy, and related thermodynamic functions. Reaction Kinetics, Mechanisms and Catalysis 2017, 121, 555-577.

22. Brandová, D.; Trojan M.; Arnold M.; Paulik F.; Paulik J. Mechanism of dehydration and condensation of CuHPO4 H2O. Journal of thermal analysis 1988, 34, 1449-1454.

23. Brandová, D.; Trojan M.; Paulik F.; Paulik J. Mechanism of dehydration of ZnHPO4 · H2O. Journal of thermal analysis 1987, 32, 1923-1928.

24. Jouini, A.; Gâcon J.C.; Ferid M.; Trabelsi-Ayadi M. Luminescence and scintillation properties of praseodymium poly and diphosphates. Optical Materials 2003, 24, 175-180.

25. Yang, T.; Lin J. Hydrothermal syntheses and low temperature magnetic behaviors of ACo3(P2O7)2 $(\mathrm{A}=\mathrm{Ca}, \mathrm{Sr}, \mathrm{Ba}, \mathrm{Pb})$. Journal of Solid State Chemistry 2013, 198, 1-5.

26. Sronsri, C.; Sittipol W.; Kongpop U. Luminescence characterization of Mn-doped LiMgPO4 synthesized using different precursors. Journal of Solid State Chemistry 2021, 297, 122083.

27. Kim, C.H.; Yim H.S. The effect of tetravalent metal on dielectric property in ZrP207 and TiP207. Solid State Communications 1999, 110, 137-142.

28. Shannon, R. Revised effective ionic radii and systematic studies of interatomic distances in halides and chalcogenides. Acta Crystallographica Section A 1976, 32, 751-767.

29. Klysubun, W.; Sombunchoo P.; Deenan W.; Kongmark C. Performance and status of beamline BL8 at SLRI for X-ray absorption spectroscopy. Journal of synchrotron radiation 2012, 19, 930-936.

30. Rietveld, H. A profile refinement method for nuclear and magnetic structures. Journal of Applied Crystallography 1969, 2, 65-71.

31. Rodríguez-Carvajal, J. Recent advances in magnetic structure determination by neutron powder diffraction. Physica B: Condensed Matter 1993, 192, 55-69.

32. Robertson, B.E.; Calvo C. Crystal structure of $\beta$-Cu2P207. Canadian Journal of Chemistry 1968, 46, 605-612.

33. Ferraro, J., Introductory group theory and its application to molecular structure. 2012: Springer Science \& Business Media.

34. Yano, J.; Yachandra V.K. X-ray absorption spectroscopy. Photosynthesis research 2009, 102, $241-254$.

35. Myung, S.T.; Komaba S.; Hirosaki N.; Kumagai N.; Arai K.; Kodama R.; Terada Y.; Nakai I. Emulsion drying preparation of layered LiMnxCr1-xO2 solid solution and its application to Li-ion battery cathode material. Journal of Power Sources 2003, 119, 211-215. 
36. El Jazouli, A.; Tbib B.; Demourgues A.; Gaudon M. Structure and colour of diphosphate pigments with square pyramid environment around chromophore ions $\left(\mathrm{Co}^{2+}, \mathrm{Ni}^{2+}, \mathrm{Cu}^{2+}\right)$. Dyes and Pigments 2014, 104, 67-74.

37. Chen, L.-T.; Hwang C.-S.; Sun I.L.; Chen I.-G. Luminescence and chromaticity of alkaline earth aluminate $\mathrm{M}_{\mathrm{x}} \mathrm{Sr}_{1-\mathrm{x}} \mathrm{Al}_{2} \mathrm{O}_{4}: \mathrm{Eu}^{2+}(\mathrm{M}: \mathrm{Ca}, \mathrm{Ba})$. Journal of Luminescence $2006,118,12-20$.

38. Kukliński, B.; Wileńska D.; Mahlik S.; Szczodrowski K.; Grinberg M.; Kłonkowski A.M. Luminescent $\mathrm{GeO}_{2}-\mathrm{Pb}-\mathrm{Bi}_{2} \mathrm{O}_{3}$ glasses co-doped with $\mathrm{Tb}^{3+1}$ and $\mathrm{Eu}^{3+}$ : Excitation energy transfer and color chromaticity. Optical Materials 2014, 36, 633-638.

39. Kim, B.-K.; Park R.-H. Detection and correction of purple fringing using color desaturation in the $x y$ chromaticity diagram and the gradient information. Image and Vision Computing 2010, 28, 952-964.

40. Sebastian, M.T., Dielectric materials for wireless communication. 2008, Amsterdam; Boston: Elsevier. xiii, 671 p., 2 p. of plates.

41. Bosman, A.J.; Havinga E.E. Temperature Dependence of Dielectric Constants of Cubic lonic Compounds. Physical Review 1963, 129, 1593-1600.

42. Voronin, V.I.; Berger I.F.; Cherepanov V.A.; Gavrilova L.Y.; Petrov A.N.; Ancharov A.I.; Tolochko B.P.; Nikitenko S.G. Neutron diffraction, synchrotron radiation and EXAFS spectroscopy study of crystal structure peculiarities of the lanthanum nickelates $\mathrm{La}^{\mathrm{n}+1} \mathrm{Ni}^{\mathrm{n}} \mathrm{O}_{\mathrm{y}}(\mathrm{n}=1,2,3)$. Nuclear Instruments and Methods in Physics Research Section A: Accelerators, Spectrometers, Detectors and Associated Equipment 2001, 470, 202-209.

43. L, Y.; Huliyageqi B.; Haschaolu W.; Song Z.; Tegus O.; Nakai I. EXAFS study of $\mathrm{Mn}_{1.28} \mathrm{Fe}_{0.67} \mathrm{P}_{0.46} \mathrm{Si}_{0.54}$ compound with first-order phase transition. Journal of Electron Spectroscopy and related Phenomena 2014, 196, 104-109.

44. Sronsri, C.; Boonchom B. Synthesis, characterization, vibrational spectroscopy, and factor group analysis of partially metal-doped phosphate materials. Spectrochimica Acta Part A: Molecular and Biomolecular Spectroscopy 2018, 194, 230-240.

45. Boonchom, B.; Phuvongpha N. Synthesis of new binary cobalt iron pyrophosphate CoFeP207. Materials Letters 2009, 63, 1709-1711.

46. Pogorzelec-Glaser, K.; Pietraszko A.; Hilczer B.; Polomska M. Structure and phase transitions in Cu2P207. Phase Transitions 2006, 79, 535-544.

47. Robertson, B.E.; Calvo C. The crystal structure and phase transformation of [alpha]-Cu2P207. Acta Crystallographica 1967, 22, 665-672.

48. Bian, J.-j.; Kim D.-W.; Hong K.S. Microwave dielectric properties of Ca2P207. Journal of the European Ceramic Society 2003, 23, 2589-2592.

49. Swanson, D.K.; Peterson R.C. Polyhedral volume calculations. The Canadian Mineralogist 1980, 18, 153-156.

50. Baur, W. The geometry of polyhedral distortions. Predictive relationships for the phosphate group. Acta Crystallographica Section B 1974, 30, 1195-1215. 
Figures

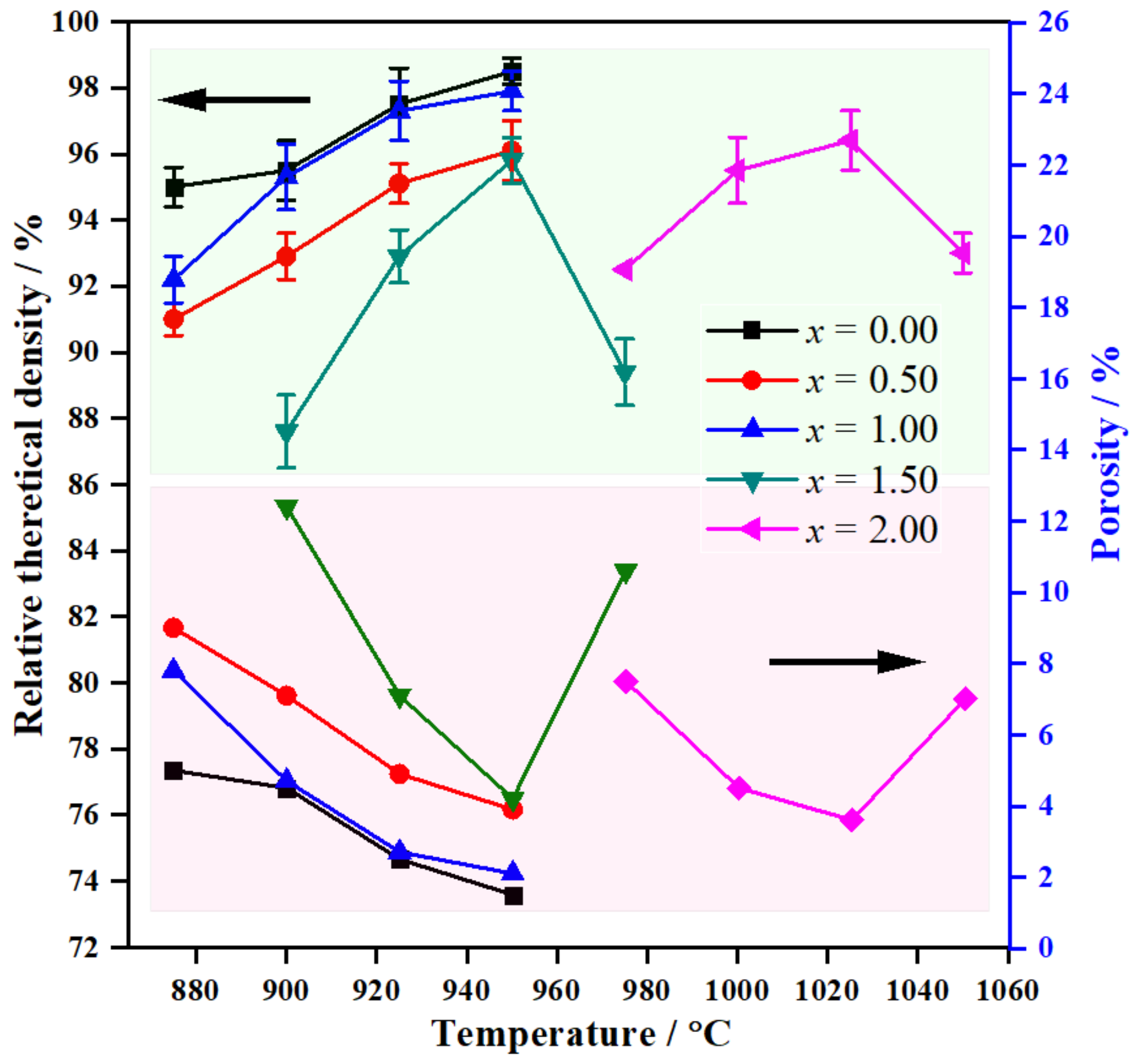

Figure 1

Relative theoretical densities (\%) and porosities (\%) of all prepared metal pyrophosphates $\left(\mathrm{Ca}_{2-x} \mathrm{Cu}_{x} \mathrm{P}_{2} \mathrm{O}_{7} ; x\right.$ $=0.00-2.00)$ 


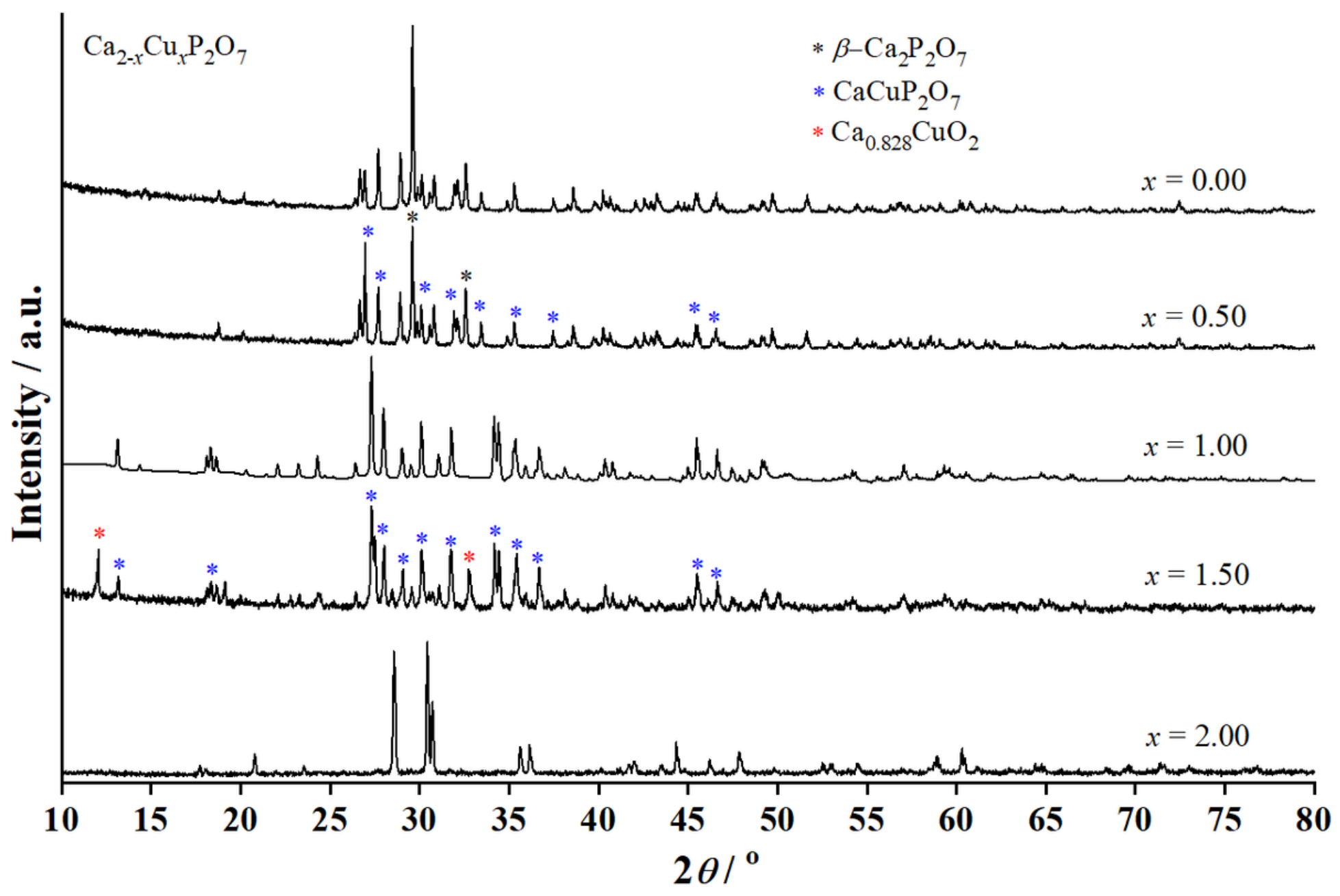

Figure 2

X-ray diffraction (XRD) patterns of the $\mathrm{Ca}_{2-x} \mathrm{Cu}_{x} \mathrm{P}_{2} \mathrm{O}_{7}$ powders $(x=0.00-2.00)$ that synthesized from the solid-state thermal decomposition of homogenized $\left(\mathrm{NH}_{4}\right)_{2} \mathrm{HPO}_{4}, \mathrm{CuO}$, and $\mathrm{CaO}$ 


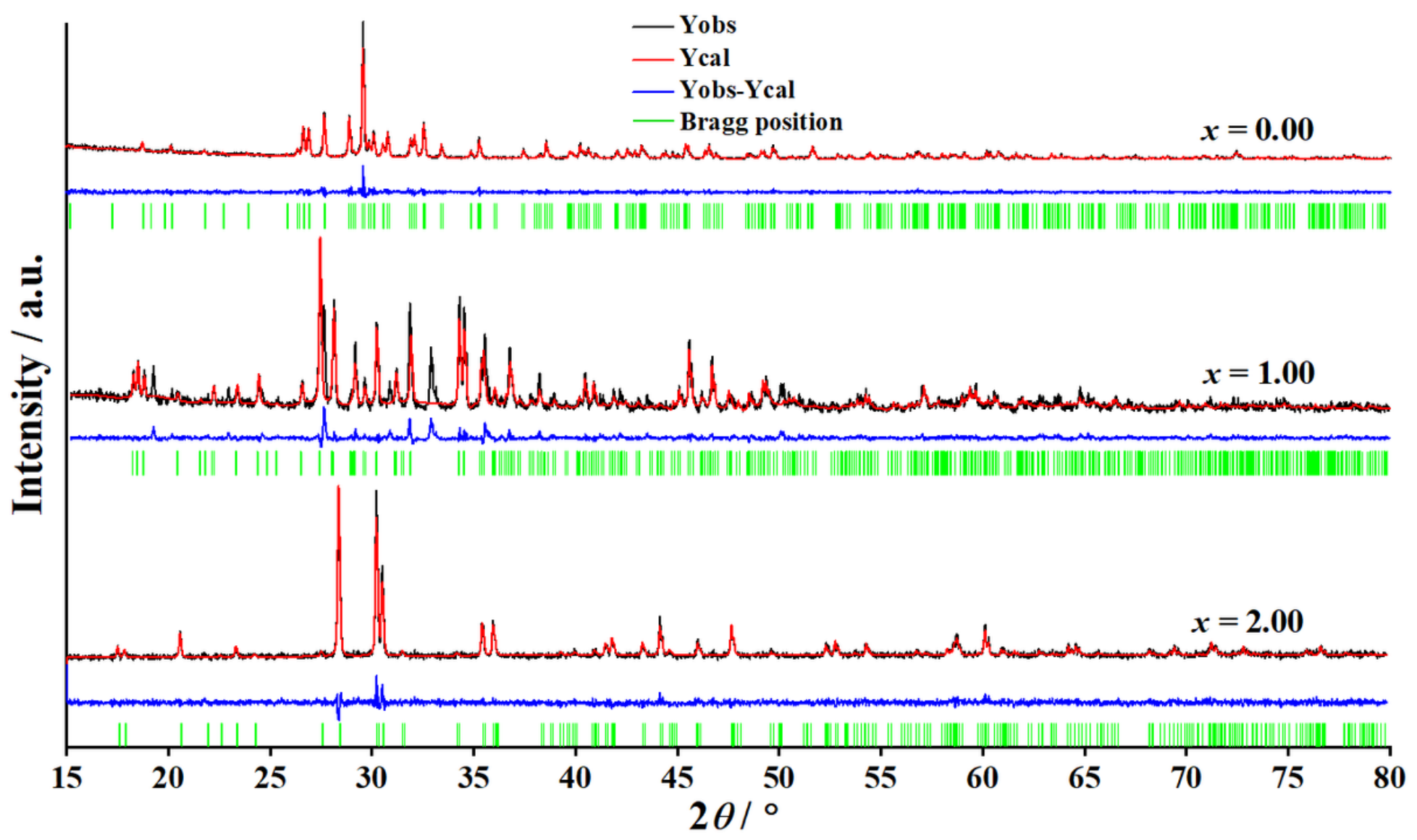

Figure 3

Rietveld refinement analytic results of the synthesized $\mathrm{Ca}_{2-x} \mathrm{Cu}_{x} \mathrm{P}_{2} \mathrm{O}_{7}$ samples, when $x=0.00,1.00$, and 2.00 


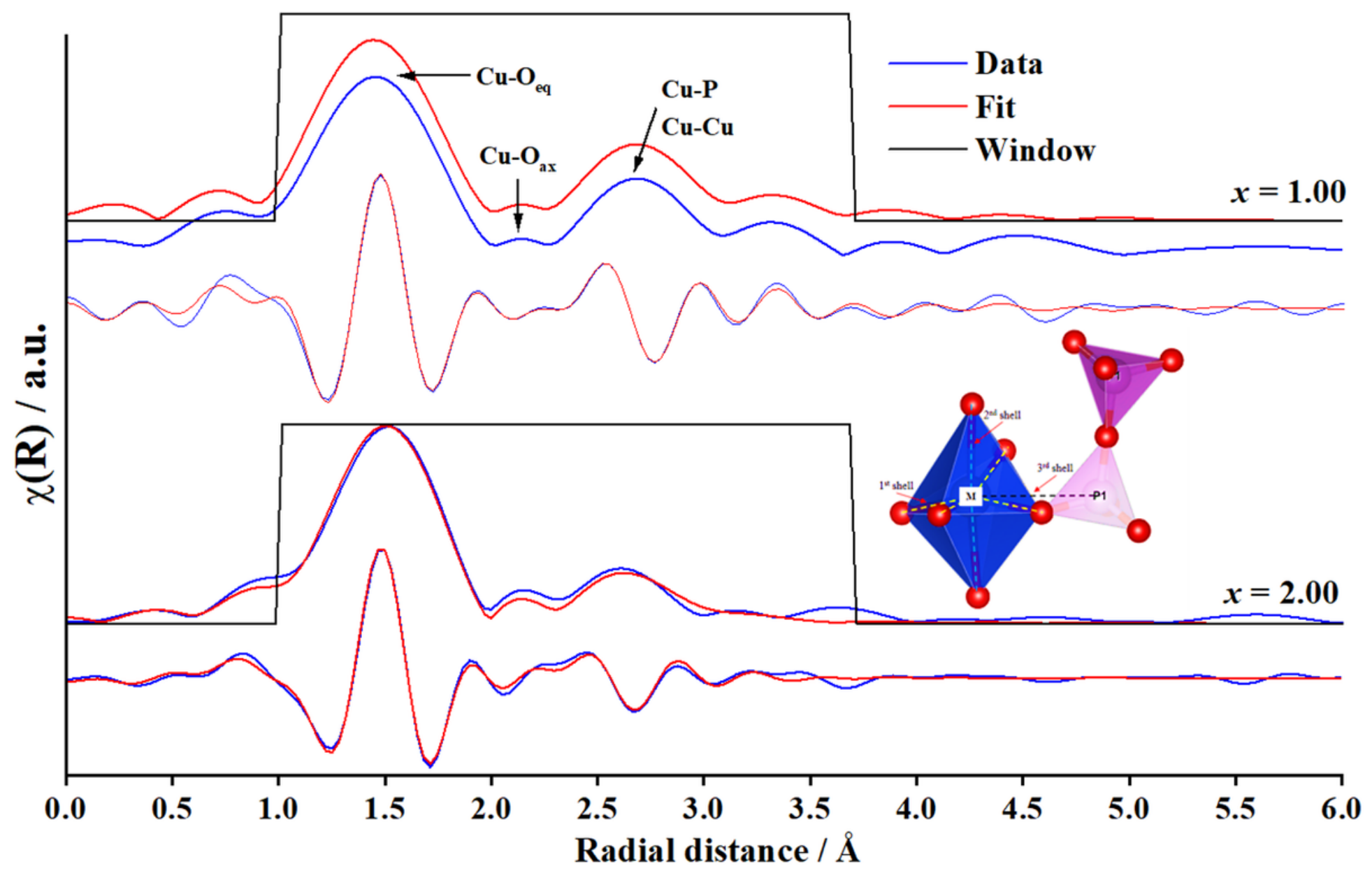

Figure 4

Local environment of $\mathrm{Ca}$ atoms when they entered the $\mathrm{Cu}_{2} \mathrm{P}_{2} \mathrm{O}_{7}$ structure, resulting in the formations of $\mathrm{Ca}_{2-x} \mathrm{Cu}_{x} \mathrm{P}_{2} \mathrm{O}_{7}$ 


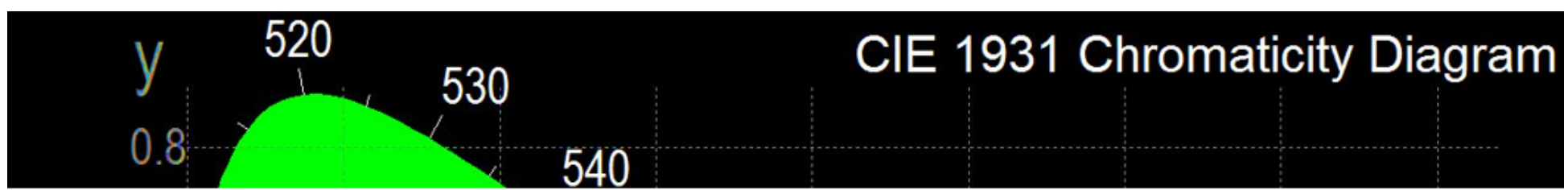

\section{Figure 5}

Optical properties and corresponding $\mathrm{CIE}$ (International Commission on Illumination) chromatic coordinates of the $\mathrm{Ca}_{2-x} \mathrm{Cu}_{x} \mathrm{P}_{2} \mathrm{O}_{7} ; x=0.00-2.00$ 


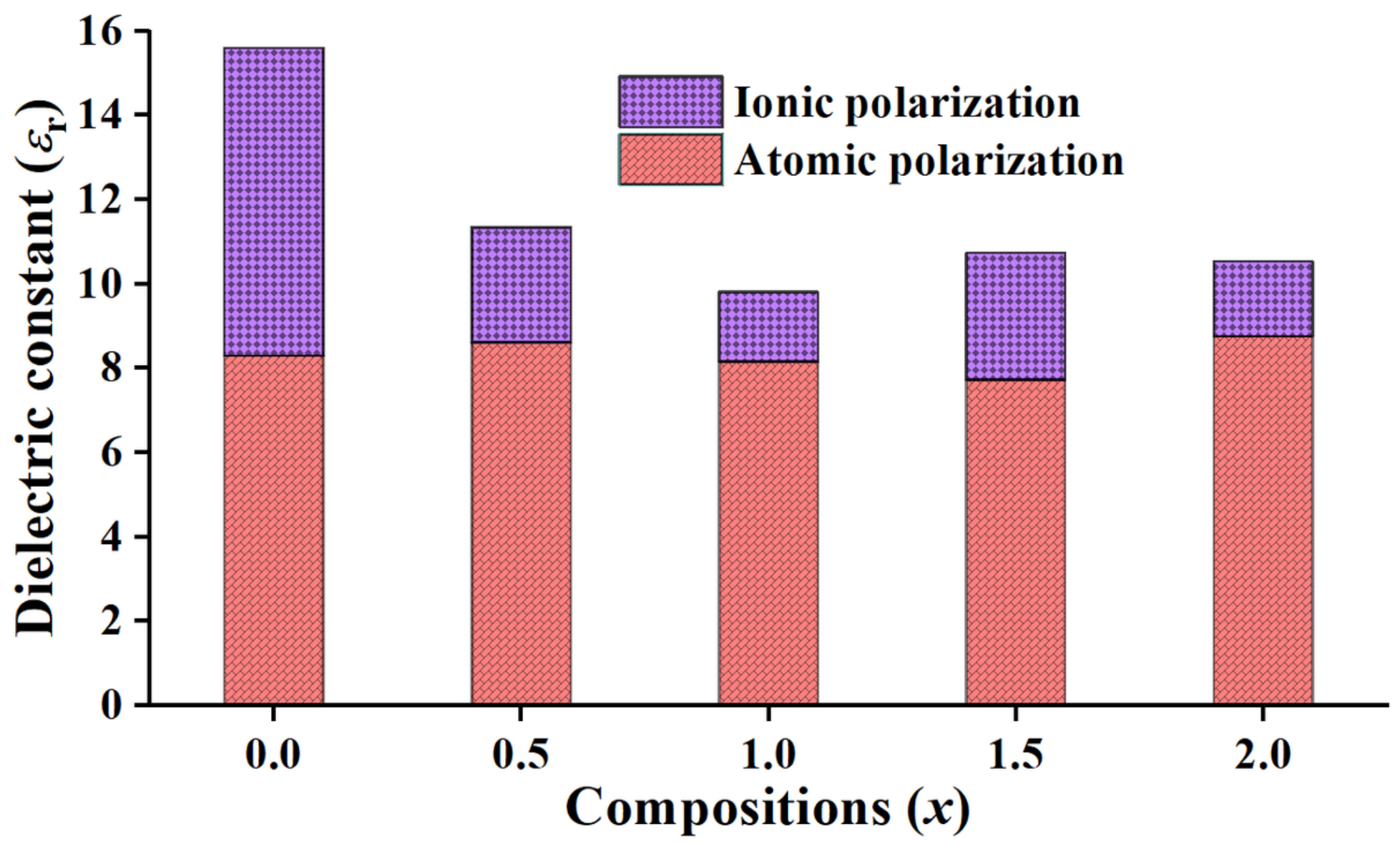

Figure 6

Dielectric constant as a function of the composition $x$ of the $\mathrm{Ca}_{2-x} \mathrm{Cu}_{x} \mathrm{P}_{2} \mathrm{O}_{7} ; x=0.00-2.00$

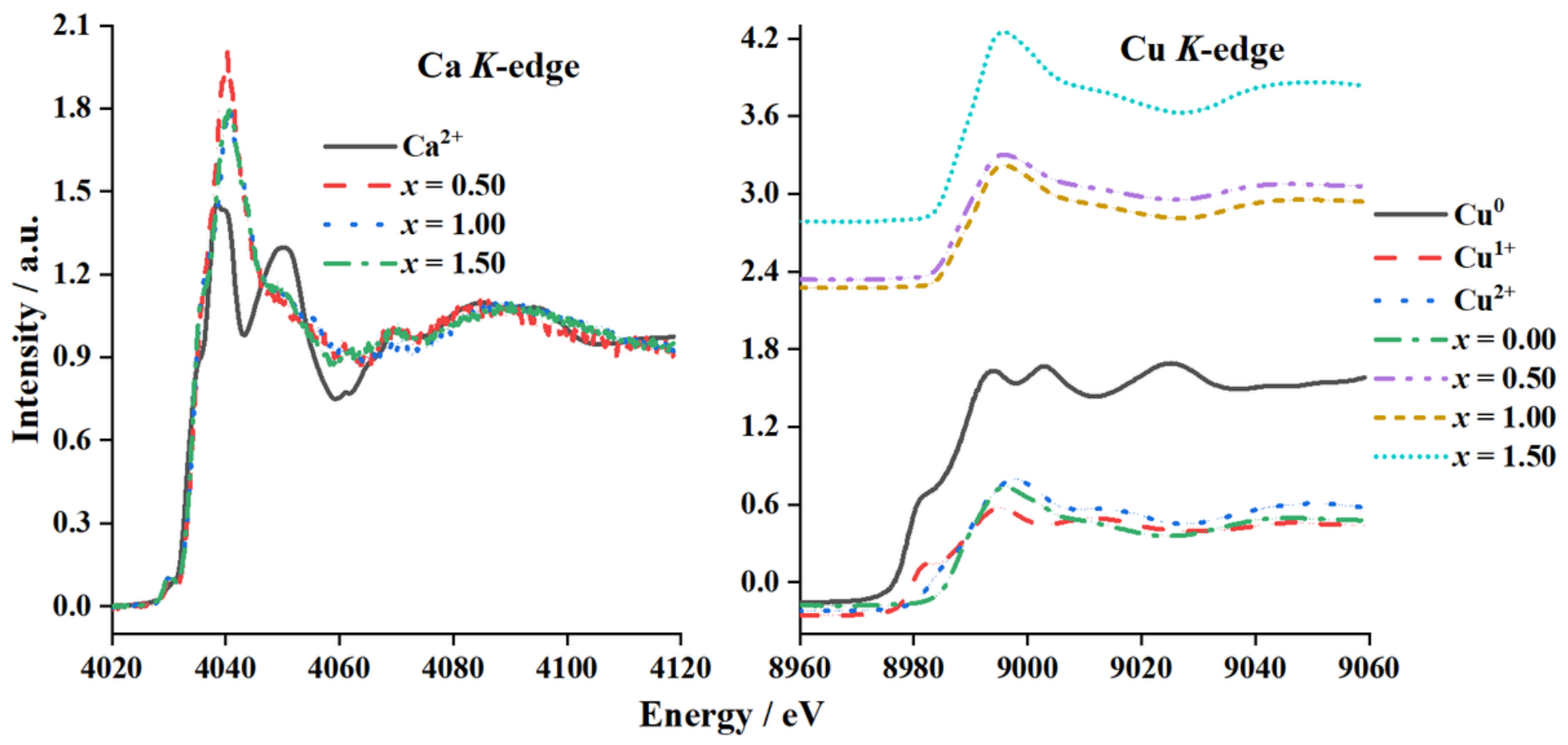


Figure 7

Extended X-ray absorption fine structure (EXAFS) spectra of the $\mathrm{Cu}^{0}, \mathrm{Cu}^{1+}, \mathrm{Cu}^{2+}, \mathrm{Ca}^{2+}$, and $\mathrm{Ca}_{2-} \mathrm{Cu}_{x} \mathrm{P}_{2} \mathrm{O}_{7} ; x$ $=0.00-1.50$

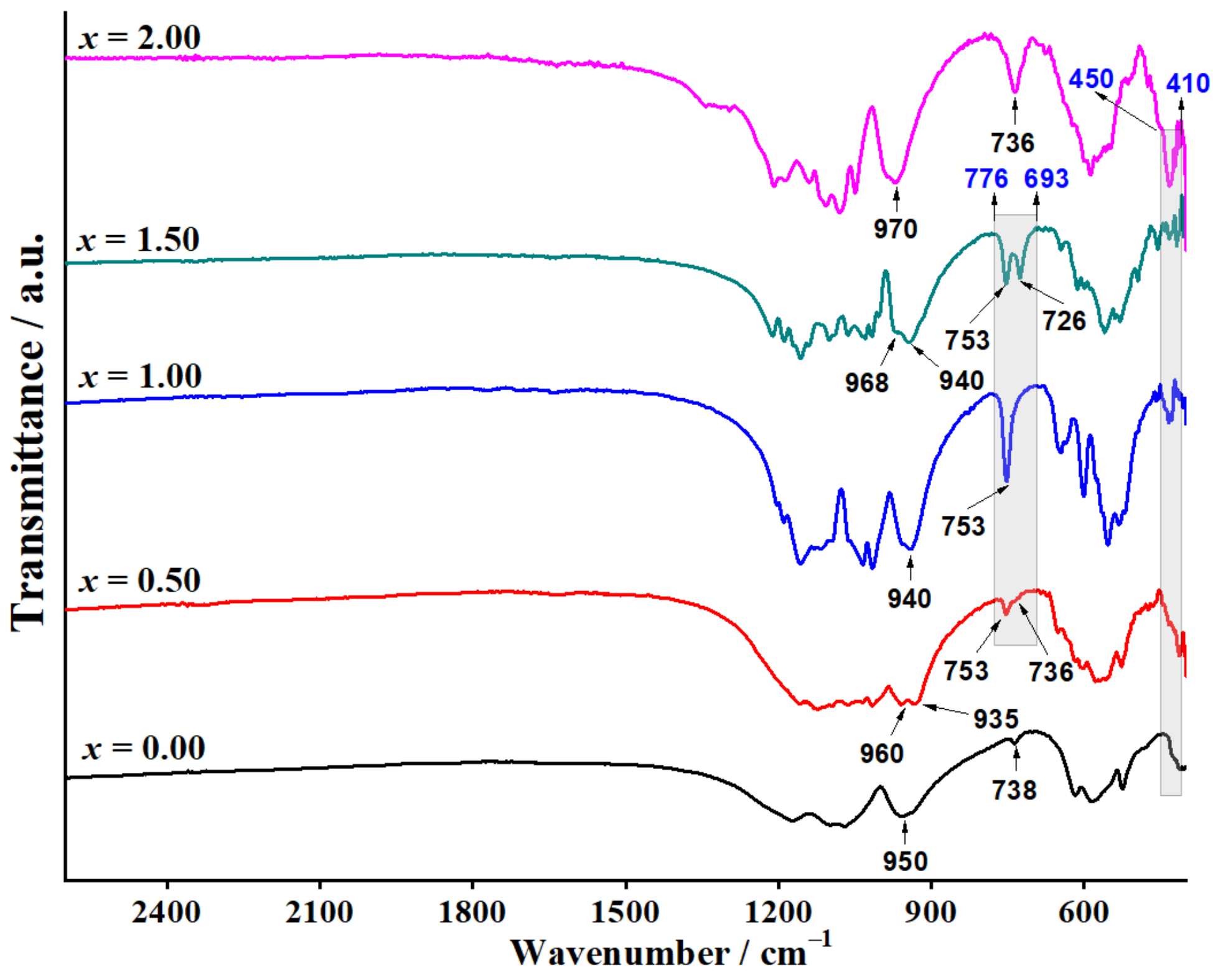

Figure 8

Fourier-transform infrared (FTIR) spectra of the synthesized $\mathrm{Ca}_{2-x} \mathrm{Cu}_{x} \mathrm{P}_{2} \mathrm{O}_{7} ; x=0.00-2.00$ 


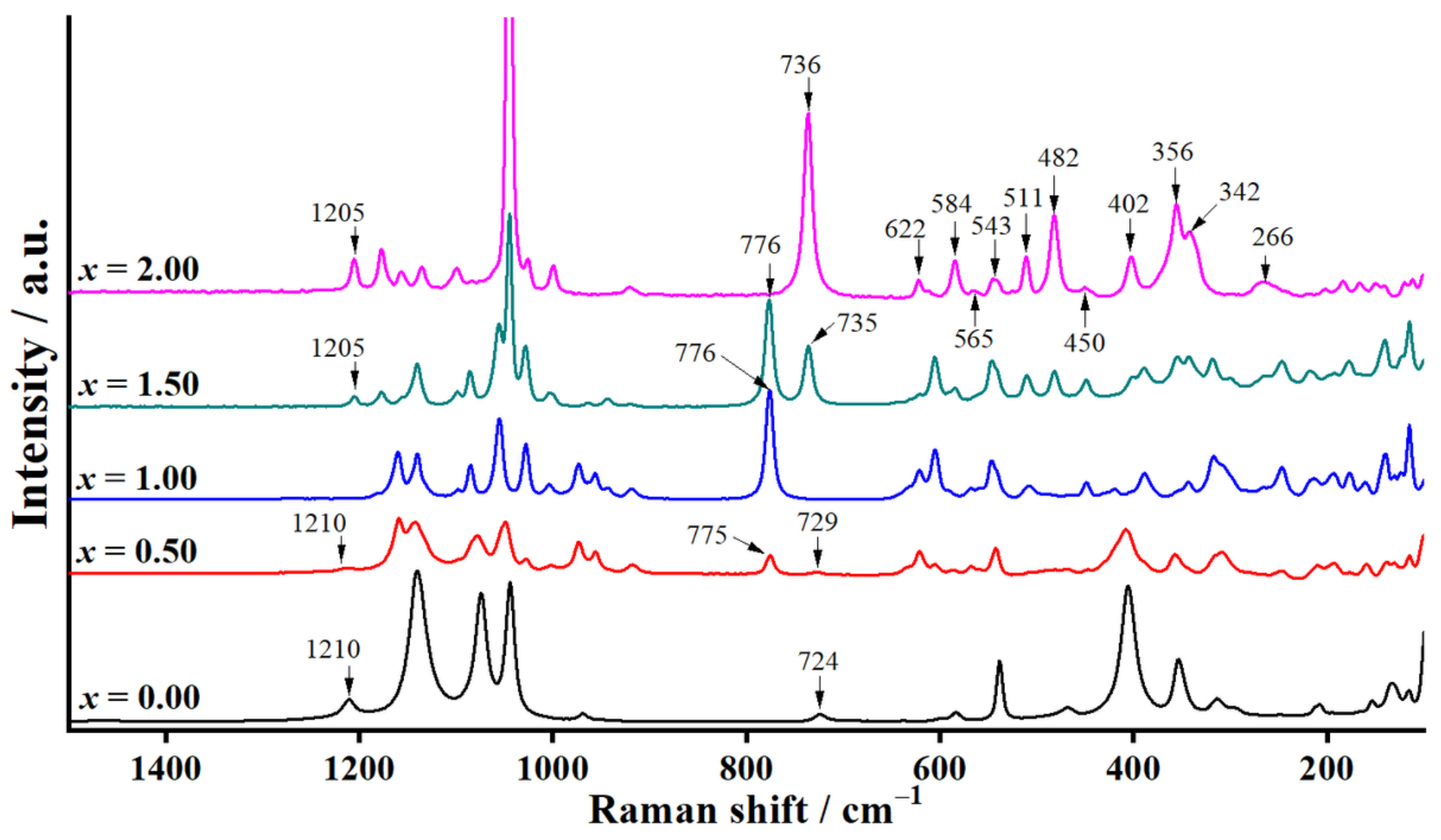

Figure 9

Raman spectra of the synthesized $\mathrm{Ca}_{2-x} \mathrm{Cu}_{x} \mathrm{P}_{2} \mathrm{O}_{7}$ compounds when $x=0.00-2.00$ 


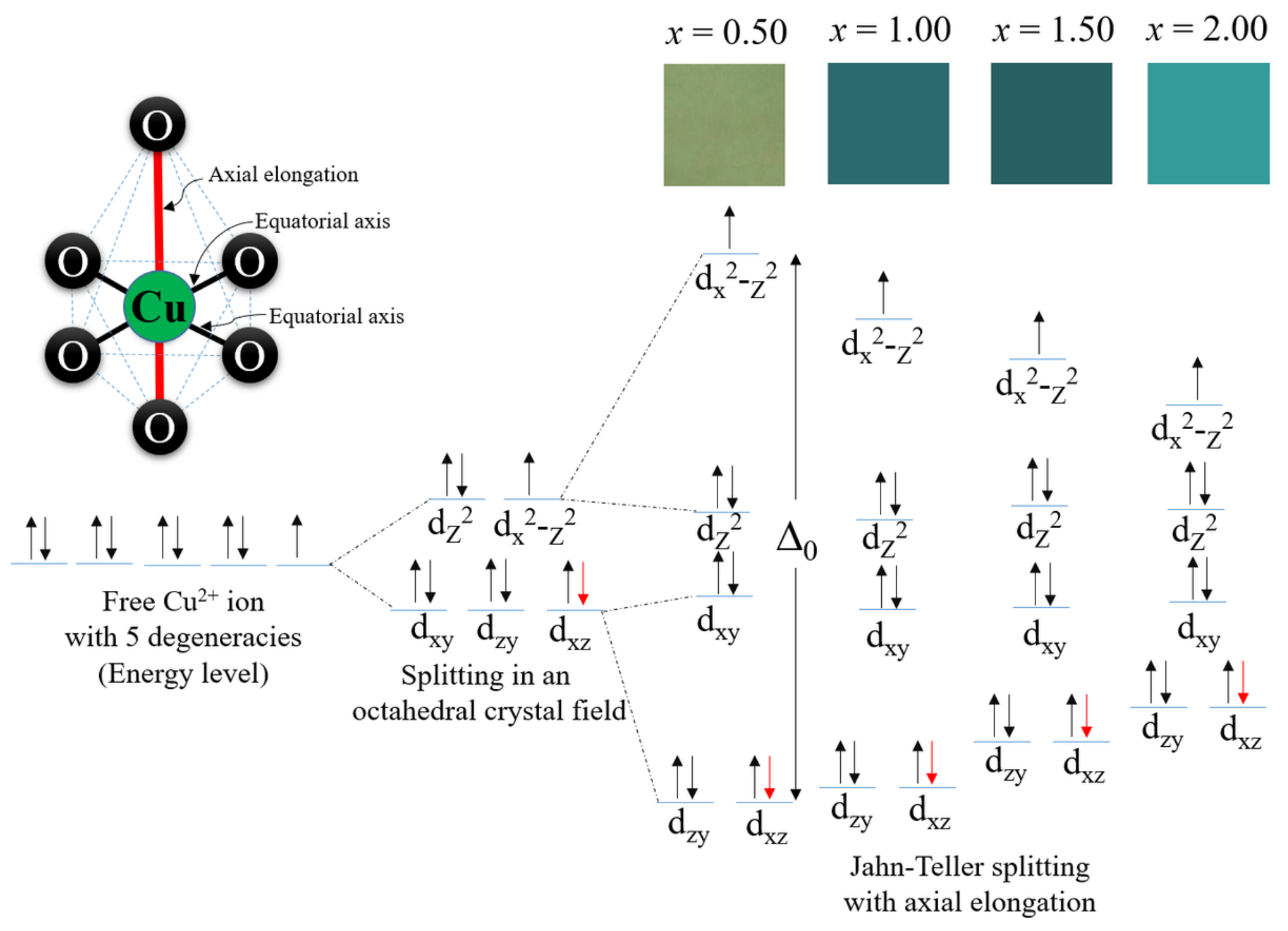

Figure 10

Octahedral splitting diagram of the synthesized $\mathrm{Ca}_{2-x} \mathrm{Cu}_{x} \mathrm{P}_{2} \mathrm{O}_{7}$ samples; $x=0.50-2.00$ 